\title{
LEVEL II SCOUR ANALYSIS FOR BRIDGE 17 (POMFTH00010017) on TOWN HIGHWAY 1 (FAS 166), crossing MILL BROOK, POMFRET, VERMONT
}

U.S. Geological Survey Open-File Report 97-2

Prepared in cooperation with

VERMONT AGENCY OF TRANSPORTATION and

FEDERAL HIGHWAY ADMINISTRATION 


\section{LEVEL II SCOUR ANALYSIS FOR BRIDGE 17 (POMFTH00010017) on TOWN HIGHWAY 1 (FAS 166), crossing MILL BROOK, POMFRET, VERMONT \\ By Erick M. Boehmler and Robert E. Hammond}

U.S. Geological Survey Open-File Report 97-2

Prepared in cooperation with

VERMONT AGENCY OF TRANSPORTATION

and

FEDERAL HIGHWAY ADMINISTRATION 


\title{
U.S. DEPARTMENT OF THE INTERIOR BRUCE BABBITT, Secretary
}

\author{
U.S. GEOLOGICAL SURVEY \\ Gordon P. Eaton, Director
}

For additional information write to:

District Chief

U.S. Geological Survey 361 Commerce Way

Pembroke, NH 03275-3718
Copies of this report may be purchased from:

U.S. Geological Survey

Branch of Information Services

Open-File Reports Unit

Box 25286

Denver, CO 80225-0286 


\section{CONTENTS}

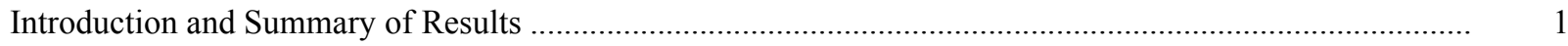

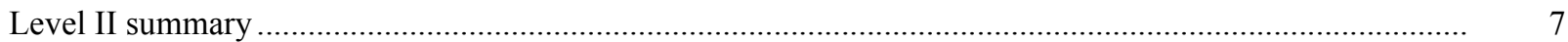

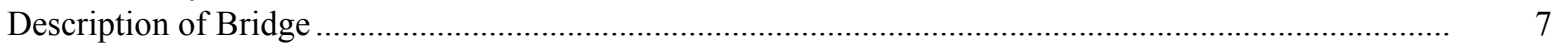

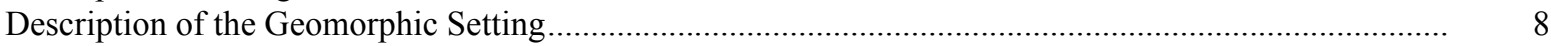

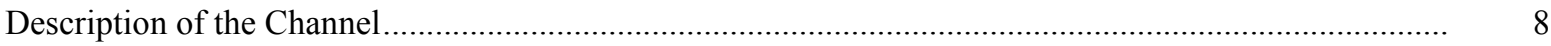

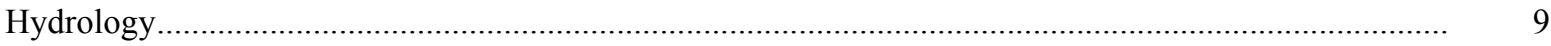

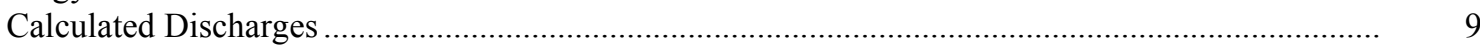

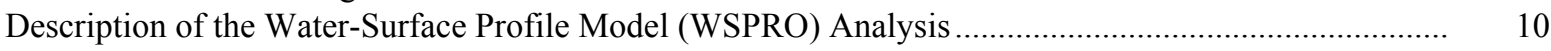

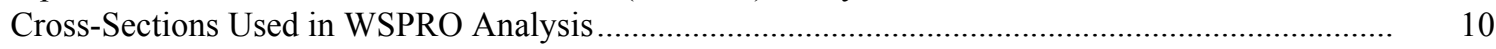

Data and Assumptions Used in WSPRO Model ...................................................................... 11

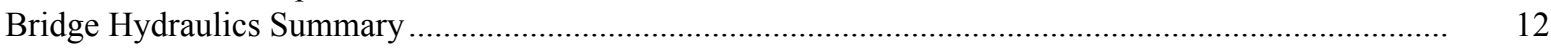

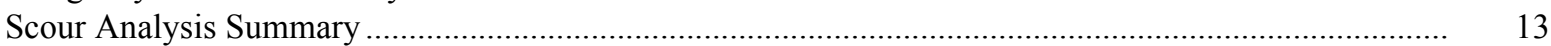

Special Conditions or Assumptions Made in Scour Analysis ...................................................... 13

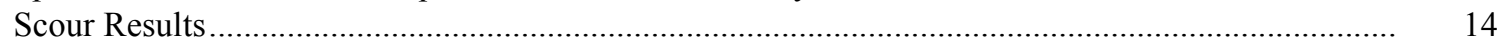

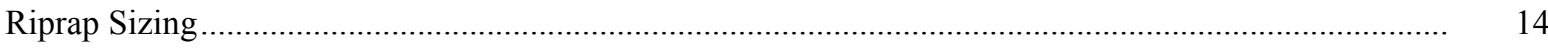

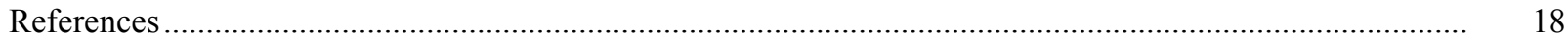

Appendixes:

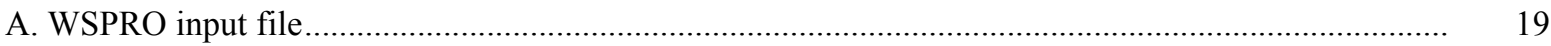

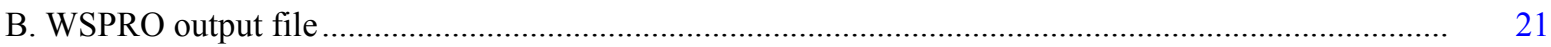

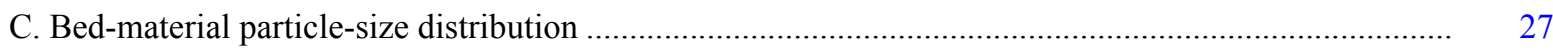

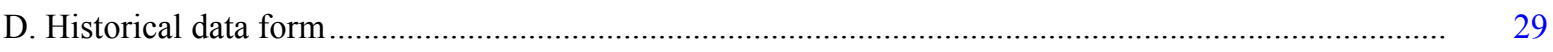

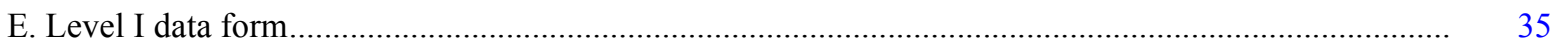

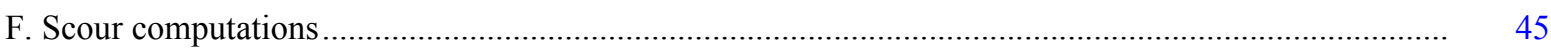

\section{FIGURES}

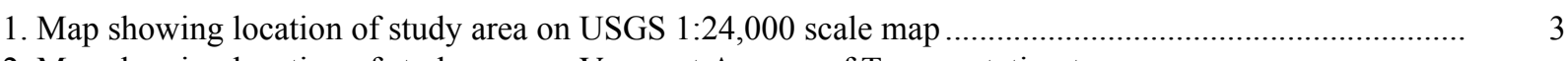

2. Map showing location of study area on Vermont Agency of Transportation town
highway map

3. Structure POMFTH00010017 viewed from upstream (July 25, 1996) …............................................... 5

4. Downstream channel viewed from structure POMFTH00010017 (July 25, 1996).............................. 5

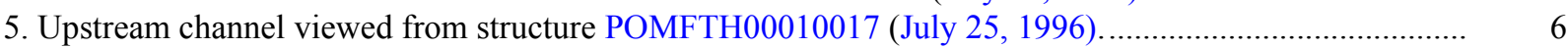

6. Structure POMFTH00010017 viewed from downstream (July 25, 1996).......................................... 6

7. Water-surface profiles for the 100- and 500-year discharges at structure

POMFTH00010017 on Town Highway 1, crossing Mill Brook,

Pomfret, Vermont.

8. Scour elevations for the 100- and 500-year discharges at structure

POMFTH00010017 on Town Highway 1, crossing Mill Brook,

Pomfret, Vermont.

\section{TABLES}

1. Remaining footing/pile depth at abutments for the 100-year discharge at structure

POMFTH00010017 on Town Highway 1, crossing Mill Brook,

Pomfret, Vermont.

2. Remaining footing/pile depth at abutments for the 500-year discharge at structure

POMFTH00010017 on Town Highway 1, crossing Mill Brook,

Pomfret, Vermont.

5




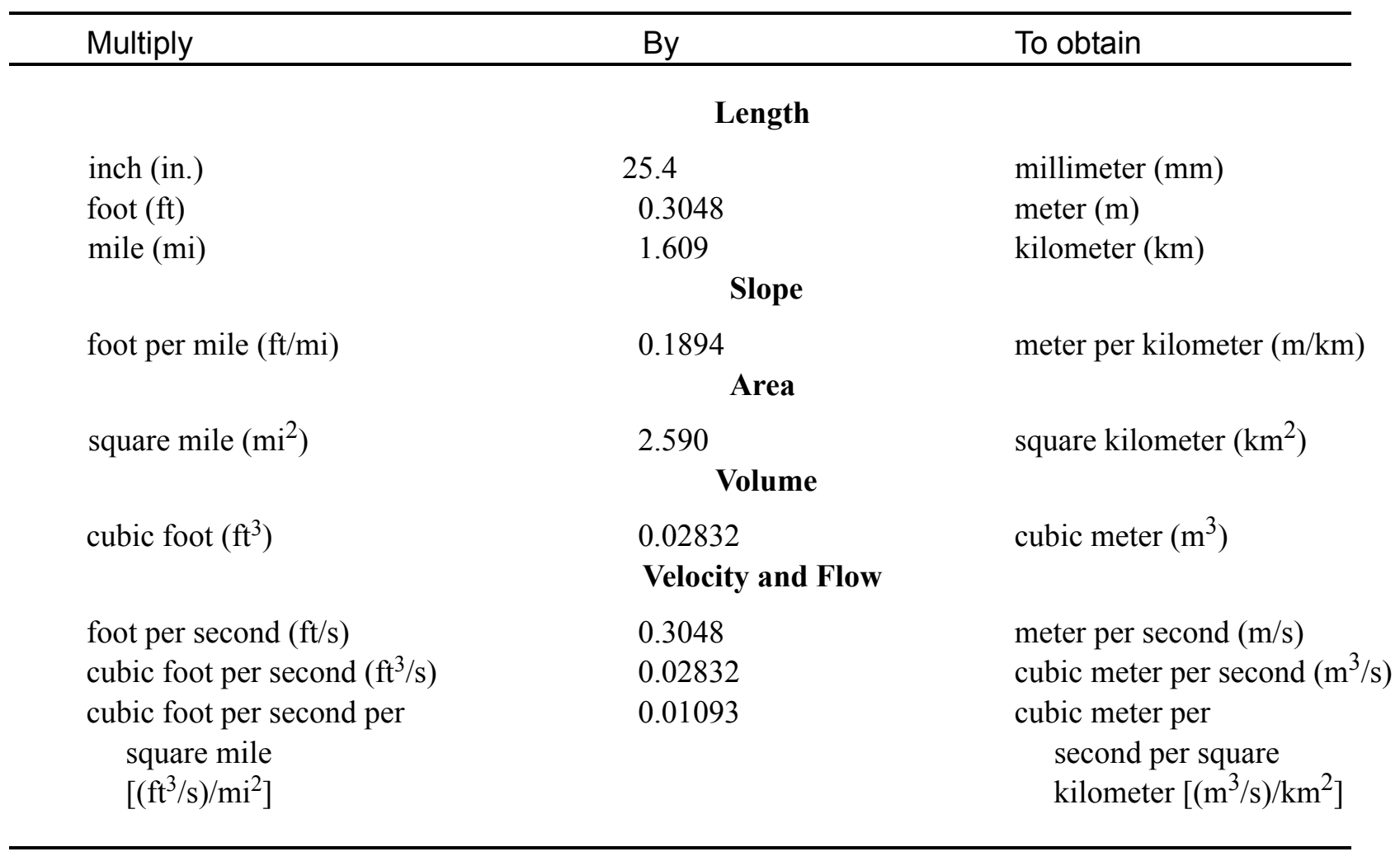

\section{OTHER ABBREVIATIONS}

$\begin{array}{lrlr}\mathrm{BF} & \text { bank full } & \text { LWW } & \text { left wingwall } \\ \mathrm{cfs} & \text { cubic feet per second } & \text { MC } & \text { main channel } \\ \mathrm{D}_{50} & \text { median diameter of bed material } & \text { RAB } & \text { right abutment } \\ \mathrm{DS} & \text { downstream } & \text { RABUT } & \text { face of right abutment } \\ \mathrm{elev} & \text { elevation } & \text { RB } & \text { right bank } \\ \mathrm{f} / \mathrm{p} & \text { flood plain } & \text { ROB } & \text { right overbank } \\ \mathrm{ft}^{2} & \text { square feet } & \text { RWW } & \text { right wingwall } \\ \mathrm{ft} / \mathrm{ft} & \text { feet per foot } & \text { TH } & \text { town highway } \\ \mathrm{JCT} & \text { junction } & \text { UB } & \text { under bridge } \\ \mathrm{LAB} & \text { left abutment } & \text { US } & \text { upstream } \\ \mathrm{LABUT} & \text { face of left abutment } & \text { USGS } & \text { United States Geological Survey } \\ \mathrm{LB} & \text { left bank } & \text { VTAOT Vermont Agency of Transportation } \\ \mathrm{LOB} & \text { left overbank } & \text { WSPRO } & \text { water-surface profile model }\end{array}$

In this report, the words "right" and "left" refer to directions that would be reported by an observer facing downstream. Sea level: In this report, "sea level" refers to the National Geodetic Vertical Datum of 1929-- a geodetic datum derived from a general adjustment of the first-order level nets of the United States and Canada, formerly called Sea Level Datum of 1929.

In the appendices, the above abbreviations may be combined. For example, USLB would represent upstream left bank. 


\title{
LEVEL II SCOUR ANALYSIS FOR BRIDGE 17 (POMFTH00010017) ON TOWN HIGHWAY 1 (FAS166), CROSSING MILL BROOK, POMFRET, VERMONT
}

\author{
By Erick M. Boehmler and Robert E. Hammond
}

\section{INTRODUCTION AND SUMMARY OF RESULTS}

This report provides the results of a detailed Level II analysis of scour potential at structure POMFTH00010017 on Town Highway 1 crossing Mill Brook, Pomfret, Vermont (figures 1-8). A Level II study is a basic engineering analysis of the site, including a quantitative analysis of stream stability and scour (U.S. Department of Transportation, 1993). Results of a Level I scour investigation also are included in Appendix E of this report. A Level I investigation provides a qualitative geomorphic characterization of the study site. Information on the bridge, gleaned from Vermont Agency of Transportation (VTAOT) files, was compiled prior to conducting Level I and Level II analyses and is found in Appendix D.

The site is in the Green Mountain section of the New England physiographic province in central Vermont. The $8.11-\mathrm{mi}^{2}$ drainage area is in a predominantly rural and forested basin. In the vicinity of the study site, the surface cover is pasture.

In the study area, Mill Brook has a sinuous channel with a slope of approximately $0.009 \mathrm{ft} /$ $\mathrm{ft}$, an average channel top width of $30 \mathrm{ft}$ and an average channel depth of $3 \mathrm{ft}$. The predominant channel bed materials are gravel and cobbles with a median grain size $\left(\mathrm{D}_{50}\right)$ of $71.9 \mathrm{~mm}(0.236 \mathrm{ft})$. The geomorphic assessment at the time of the Level I and Level II site visit on July 25,1996 , indicated that the reach was stable.

The Town Highway 1 crossing of Mill Brook is a 54-ft-long, two-lane bridge consisting of one 52-foot steel-beam span (Vermont Agency of Transportation, written communication, August 23, 1994). The bridge is supported by vertical, concrete abutments with spillthrough embankments. The channel is skewed approximately 15 degrees to the opening and the opening-skew-to-roadway is 15 degrees.

The scour protection measures at the site were type- 3 stone riprap (less than 48 inches diameter) on the spill-through embankments of each abutment and type- 2 stone fill (less than 24 inches diameter) on the banks downstream. Additional details describing conditions at the site are included in the Level II Summary and Appendices D and E. 
Scour depths and rock rip-rap sizes were computed using the general guidelines described in Hydraulic Engineering Circular 18 (Richardson and others, 1995). Total scour at a highway crossing is comprised of three components: 1) long-term streambed degradation; 2) contraction scour (due to accelerated flow caused by a reduction in flow area at a bridge) and; 3) local scour (caused by accelerated flow around piers and abutments). Total scour is the sum of the three components. Equations are available to compute depths for contraction and local scour and a summary of the results of these computations follows.

Contraction scour for all modelled flows ranged from 0.0 to $0.9 \mathrm{ft}$. The worst-case contraction scour occurred at the 500-year discharge. Abutment scour ranged from 3.6 to $7.1 \mathrm{ft}$. The worst-case abutment scour also occurred at the 500-year discharge. Additional information on scour depths and depths to armoring are included in the section titled "Scour Results". Scoured-streambed elevations, based on the calculated scour depths, are presented in tables 1 and 2. A cross-section of the scour computed at the bridge is presented in figure 8. Scour depths were calculated assuming an infinite depth of erosive material and a homogeneous particle-size distribution.

It is generally accepted that the Froehlich equation (abutment scour) gives "excessively conservative estimates of scour depths" (Richardson and others, 1995, p. 47). Usually, computed scour depths are evaluated in combination with other information including (but not limited to) historical performance during flood events, the geomorphic stability assessment, existing scour protection measures, and the results of the hydraulic analyses. Therefore, scour depths adopted by VTAOT may differ from the computed values documented herein. 


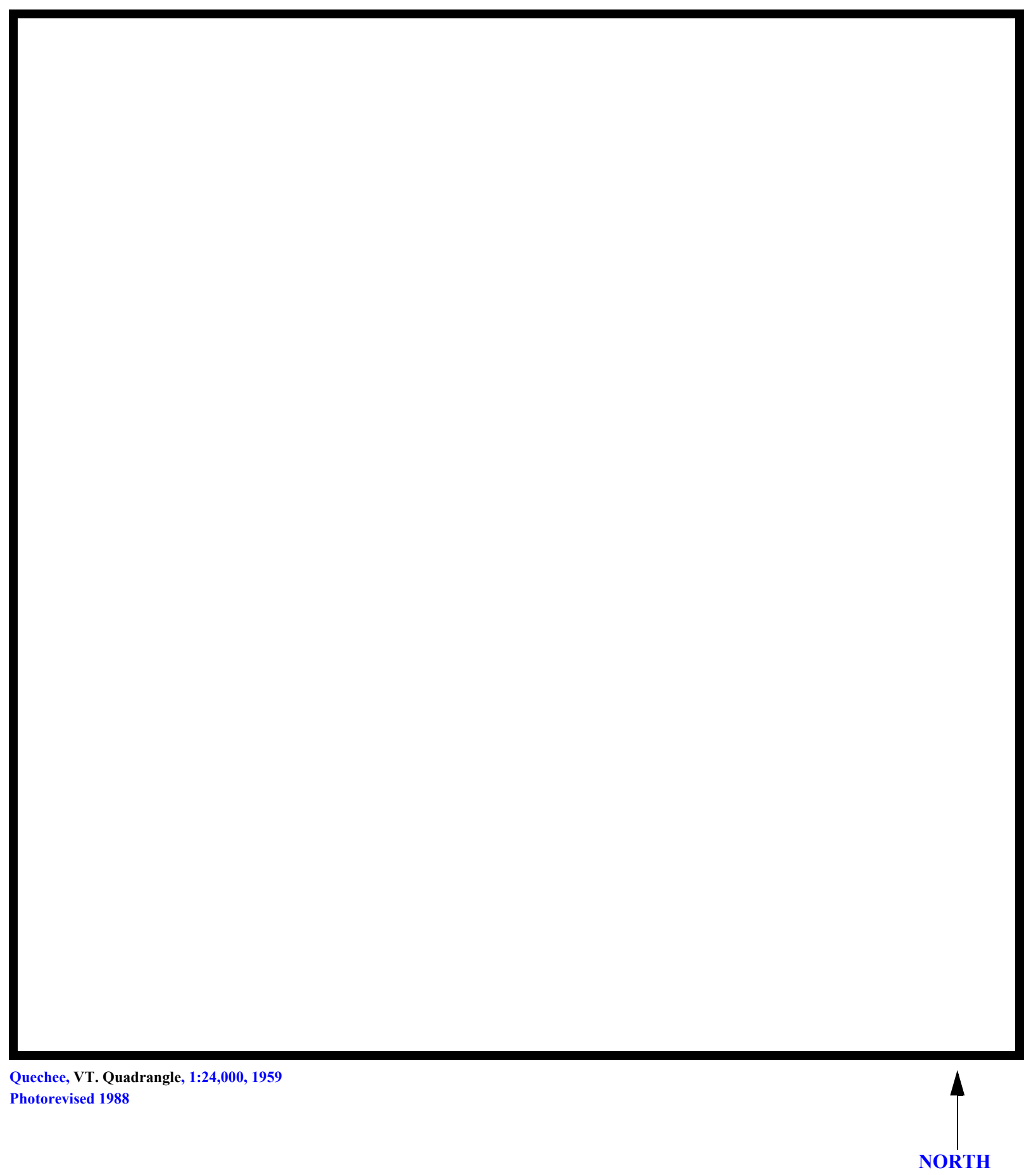

Figure 1. Location of study area on USGS 1:24,000 scale map. 
Figure 2. Location of study area on Vermont Agency of Transportation town highway map. 

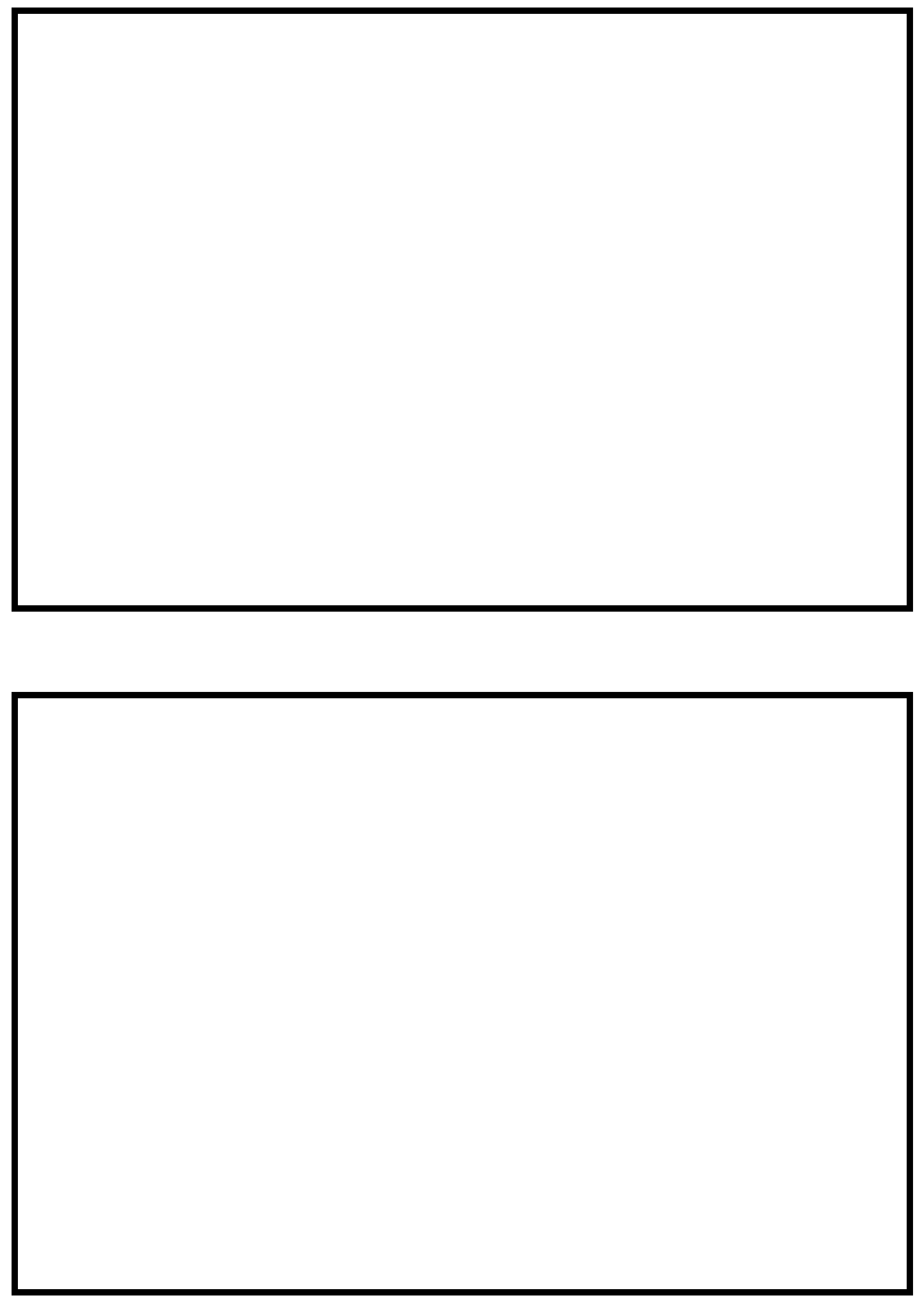

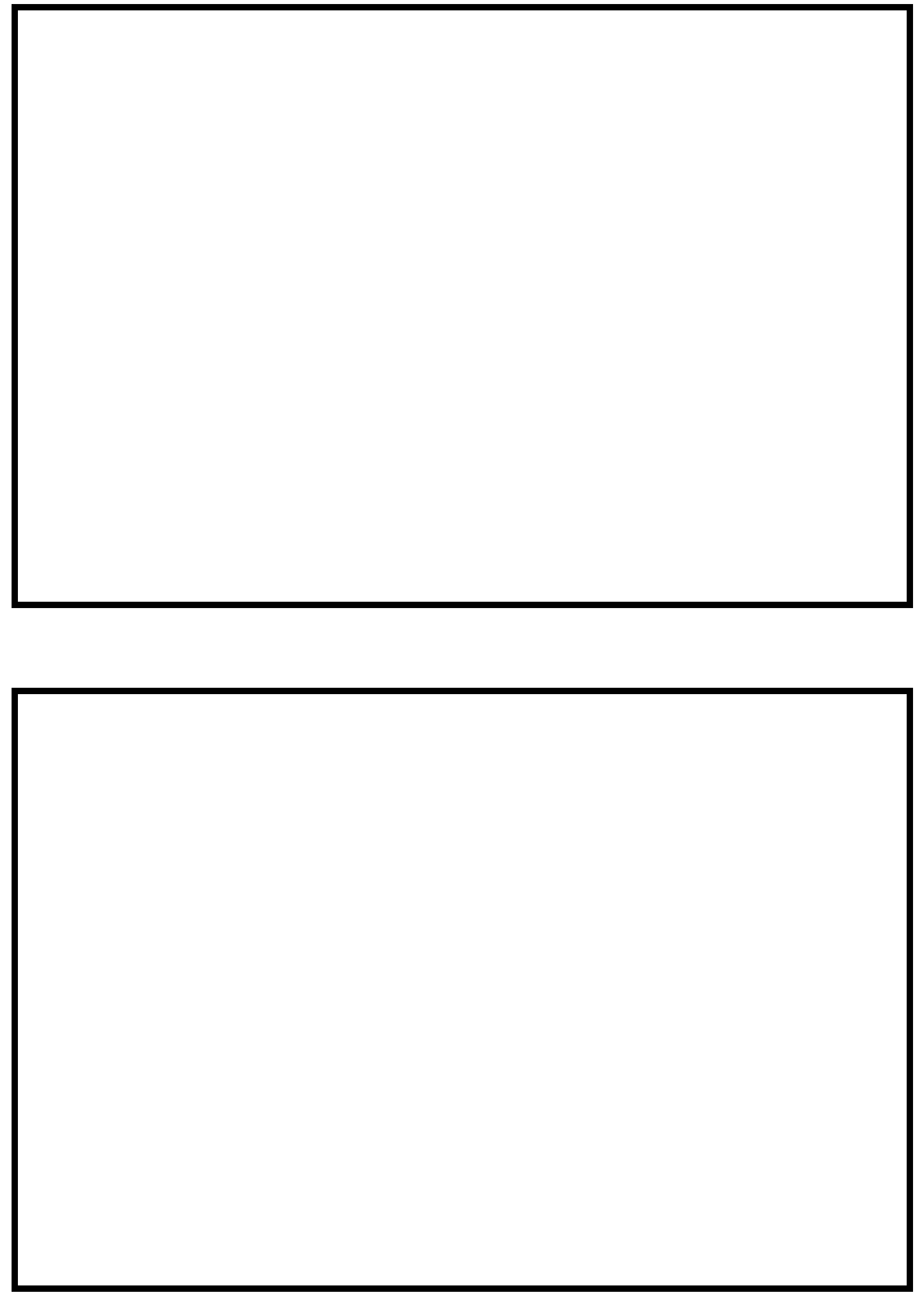


\section{LEVEL II SUMMARY}

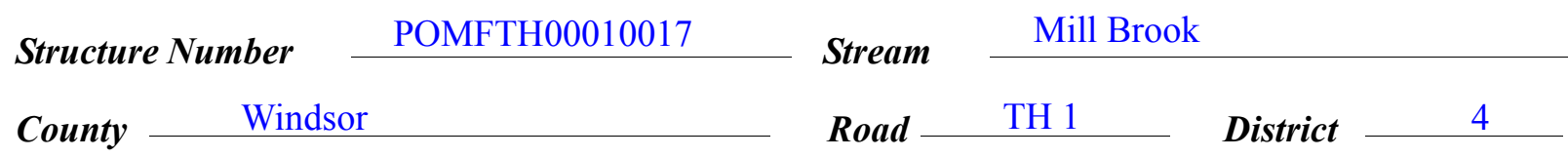

\section{Description of Bridge}

Bridge length $\frac{54}{} \boldsymbol{f t} \quad$ Bridge width $\stackrel{27.3}{f} \quad$ Max span length $\frac{52}{f t}$ Alignment of bridge to road (on curve or straight) Spill-through Abutment type

Stone fill on abutment? Yes

\section{Embankment type}

Drto af incnortion Type-3 stone riprap on each spill-through embankment and Type-2

embankments in front of each abutment wall.

\section{Y}

Sloping

$7 / 25 / 96$

\section{Is bridge skewed to flood flow according to $\mathrm{Y} \quad$ ' survey? Angle}

There is a sharp channel bend in the upstream reach which impacts the left bank. The left bank material is bedrock in the range of the impact.

Debris accumulation on bridge at time of Level I or Level II site visit:

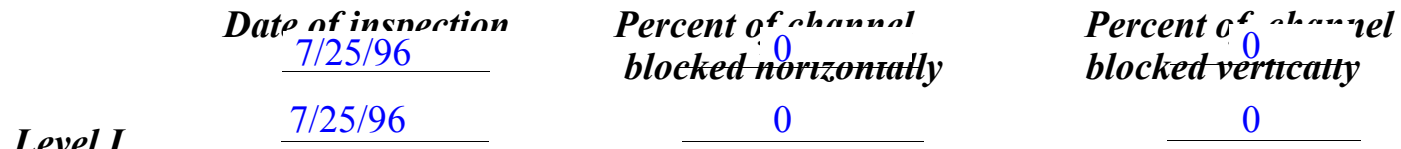

Level II Moderate. There is some debris in the channel, particularly upstream, and significant vegetation cover on locally unstable banks.

Potential for debris

None evident on 7/25/96.

Dosriho anv foaturos noar ar at tho hridoo that mav, affort flow, (includo ahsorvation dato). 


\section{Description of the Geomorphic Setting}

General topography The channel is located in a moderate relief valley setting with narrow overbanks and moderately sloping valley walls on both sides.

Geomorphic conditions at bridge site: downstream (DS), upstream (US)

Date of inspection $\quad 7 / 25 / 96$

DS left: $\quad$ Steep channel bank to a narrow overbank.

DS right: $\quad$ Steep channel bank to a narrow overbank

US left: $\quad$ Steep channel bank and valley wall.

US right: $\quad$ Moderately sloping bank to a narrow overbank.

\section{Description of the Channel}

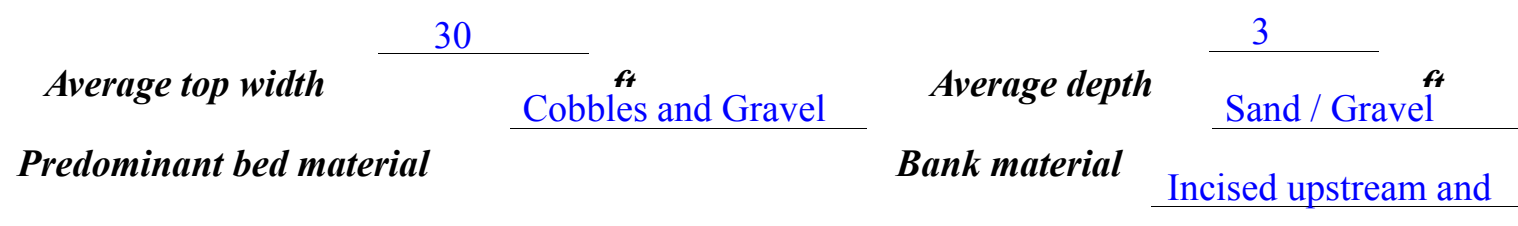

sinuous but stable with semi-alluvial channel boundaries.

Vegetative co ${ }^{\text {Dense trees and brush cover. }} . \quad \ldots \quad \ldots \quad$.

DS left: $\quad$ Brush and some trees.

DS right: $\quad$ Trees

US left: $\quad$ Grass and brush with some trees.

US right: $\quad \underline{\mathrm{Y}}$

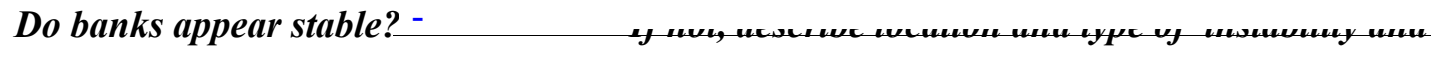

date of observatton.

None evident on

7/25/96.

Describe any obstructions in channel and date of observation. 


\title{
Hydrology
}

Drainage area $\stackrel{8.11}{\longrightarrow} \mathbf{m i}^{2}$

Percentage of drainage area in physiographic provinces: (approximate)

Physiographic province/section

New England / Green Mountain
Percent of drainage area 100

\begin{abstract}
Is drainage area considered rural or urban? Rural _ Describe any significant urbanization:
\end{abstract}

Is there a USGS gage on the stream of interest?

No

USGS gage description

USGS gage number

Gage drainage area $\mathrm{mi}^{2}$ $m i^{2}$ No

Is there a lake/p

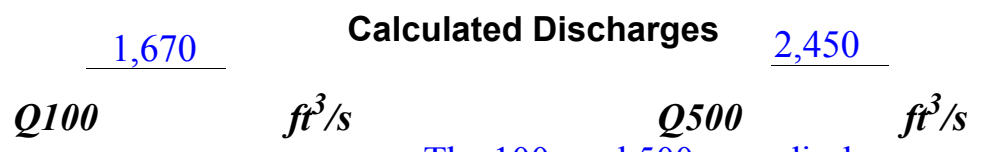

The 100- and 500-year discharges are based on

discharge frequency curves computed by use of several empirical equations (Benson, 1962;

FHWA, 1983; Johnson and Laraway, unpublished draft, 1972; Johnson and Tasker, 1974; Potter, 1957; and Talbot, 1887). The median of the 100- and 500-year discharges from each empirical discharge frequency curve was selected for the hydraulic analyses at this site. 


\section{Description of the Water-Surface Profile Model (WSPRO) Analysis}

Datum for WSPRO analysis (USGS survey, sea level, VTAOT plans)

USGS survey

Datum tie between USGS survey and VTAOT plans

Subtract 303.4 feet from the

USGS survey to obtain the VTAOT plans' datum.

Description of reference marks used to determine USGS datum. $\quad$ RM1 is the center point

of a chiseled "X" in exposed bedrock about 45 feet upstream on left bank side of the channel

(elev. $491.22 \mathrm{ft}$, arbitrary survey datum). RM2 is the center point of a chiseled " $\mathrm{X}$ " in exposed

bedrock 20 feet left of left abutment and 10 feet upstream of the upstream side of TH1 (elev.

$500.41 \mathrm{ft}$, arbitrary survey datum).

\section{Cross-Sections Used in WSPRO Analysis}

\begin{tabular}{ccll}
\hline${ }^{1}$ Cross-section & $\begin{array}{c}\text { Section } \\
\text { Reference } \\
\text { Distance } \\
\text { (SRD) } \text { in feet }\end{array}$ & $\begin{array}{c}{ }^{2} \text { Cross-section } \\
\text { development }\end{array}$ & \multicolumn{1}{c}{ Comments } \\
\hline EXITX & -48 & 1 & $\begin{array}{l}\text { Exit section } \\
\text { Downstream Full-valley } \\
\text { section (Templated from } \\
\text { FULLV }\end{array}$ \\
ERIDG & 0 & 2 & $\begin{array}{l}\text { BXITX) } \\
\text { Bridge section }\end{array}$ \\
RDWAY & 15 & 1 & $\begin{array}{l}\text { Road Grade section } \\
\text { Approach section as sur- } \\
\text { APTEM }\end{array}$ \\
& 74 & 1 & $\begin{array}{l}\text { veyed (Used as a tem- } \\
\text { plate) }\end{array}$ \\
APPRO & 79 & $\begin{array}{l}\text { Modelled Approach sec- } \\
\text { tion (Templated from } \\
\text { APTEM) }\end{array}$ \\
\hline
\end{tabular}

${ }^{1}$ For location of cross-sections see plan-view sketch included with Level I field form, Appendix E. For more detail on how cross-sections were developed see WSPRO input file. 


\section{Data and Assumptions Used in WSPRO Model}

Hydraulic analyses of the reach were done by use of the Federal Highway Administration's WSPRO step-backwater computer program (Shearman and others, 1986, and Shearman, 1990). The analyses reported herein reflect conditions existing at the site at the time of the study. Furthermore, in the development of the model it was necessary to assume no accumulation of debris or ice at the site. Results of the hydraulic model are presented in the Bridge Hydraulic Summary, Appendix B, and figure 7.

Channel roughness factors (Manning's “ $n$ ”) used in the hydraulic model were estimated using field inspections at each cross section following the general guidelines described by Arcement and Schneider (1989). Final adjustments to the values were made during the modelling of the reach. Channel " $\mathrm{n}$ " values for the reach ranged from 0.037 to 0.054 , and overbank "n" values were 0.050 .

Normal depth at the exit section (EXITX) was assumed as the starting water surface. This depth was computed by use of the slope-conveyance method outlined in the user's manual for WSPRO (Shearman, 1990). The slope used was $0.0087 \mathrm{ft} / \mathrm{ft}$ which was estimated from surveyed channel thalweg points downstream of the EXITX section.

The surveyed approach section (APTEM) was moved along the approach channel slope $(0.0102 \mathrm{ft} / \mathrm{ft})$ to establish the modelled approach section (APPRO), one bridge length upstream

of the upstream face as recommended by Shearman and others (1986). This approach also provides a consistent method for determining scour variables. 


\section{Bridge Hydraulics Summary}

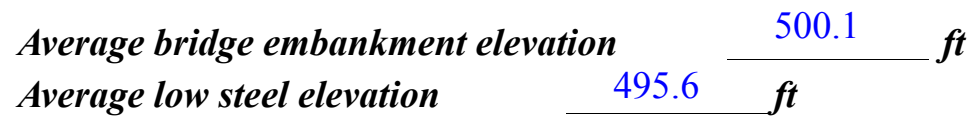

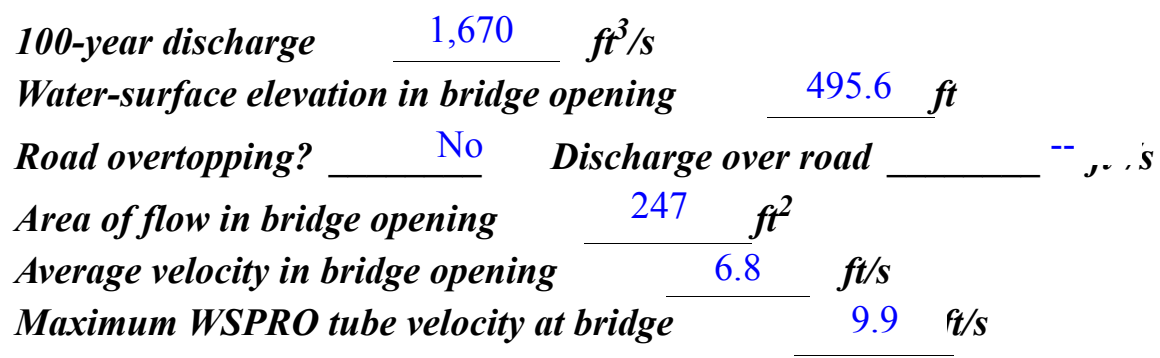

Water-surface elevation at Approach section with bridge Water-surface elevation at Approach section without bridge 496.7 Amount of backwater caused by bridge 1.4 it

500-year discharge $\quad 2,450 \quad \boldsymbol{f t}^{3} / \mathrm{s}$

Water-surface elevation in bridge opening $495.7 f t$

Road overtopping? ___ No Discharge over road ___

Area of flow in bridge opening $\quad 248 \quad \boldsymbol{f t}^{2}$

Average velocity in bridge opening $\quad 9.9 \mathrm{ft} / \mathrm{s}$

Maximum WSPRO tube velocity at bridge 12.4 's

Water-surface elevation at Approach section with bridge

Water-surface elevation at Approach section without bridge

499.2

Amount of backwater caused by bridge

2.8 .

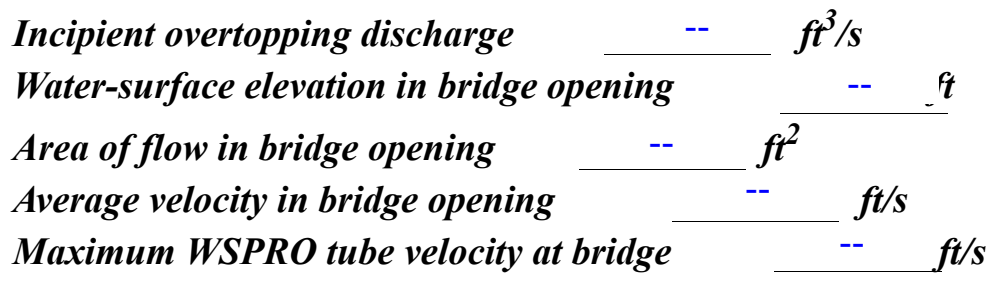

Water-surface elevation at Approach section with bridge

Water-surface elevation at Approach section without bridge

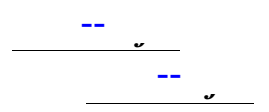
Amount of backwater caused by bridge _ 


\section{Scour Analysis Summary}

\section{Special Conditions or Assumptions Made in Scour Analysis}

Scour depths were computed using the general guidelines described in Hydraulic Engineering Circular 18 (Richardson and others, 1995). Scour depths were calculated assuming an infinite depth of erosive material and a homogeneous particle-size distribution. The results of the scour analysis are presented in tables 1 and 2 and a graph of the scour depths is presented in figure 8 .

At this site, the 100- and 500-year discharges resulted in unsubmerged orifice flow. Contraction scour at bridges with orifice flow is best estimated by use of the Chang pressureflow scour equation (oral communication, J. Sterling Jones, October 4, 1996). Therefore, contraction scour depths were computed by use of the Chang equation (Richardson and others, 1995, p. 145-146). The results of Laursen's clear-water contraction scour equation (Richardson and others, 1995, p. 32, equation 20) for each event also were computed and included in appendix F.

Abutment scour for the left abutment was computed by use of the Froehlich equation (Richardson and others, 1995, p. 48, equation 28). Variables for the Froehlich equation include the Froude number of the flow approaching the embankments, the length of the embankment blocking flow, and the depth of flow approaching the embankment less any roadway overtopping.

Scour at the right abutment for the 100- and 500-year discharges was computed by use of the HIRE equation (Richardson and others, 1995, p. 49, equation 29) because the HIRE equation is recommended when the length to depth ratio of the embankment blocking flow exceeds 25 . The variables used by the HIRE abutment-scour equation are defined the same as those defined for the Froehlich abutment-scour equation.

Because the influence of scour processes on the spill-through embankment material is uncertain, the scour depth at the vertical concrete abutment walls is unknown. Therefore, the total scour depths were applied for the entire spill-through embankment area below the elevation at the toe of each embankment, as shown in figure 8. 


\section{Scour Results}

\section{0-yr discharge 500-yr discharge}

Contraction scour:

(Scour depths in feet)

Main channel

Live-bed scour

Clear-water scour

Depth to armoring

Left overbank

Right overbank

Local scour:

Abutment scour

Left abutment

Right abutment

Pier scour

Pier 1

Pier 2

Pier 3

\section{Abutments:}

Left abutment

Right abutment

Piers:

Pier 1

Pier 2

\section{Riprap Sizing}

Incipient overtopping 100-yrdischarge 500-yrdischarge discharge (1.7 feet)

overtopping discharge

Incipient 


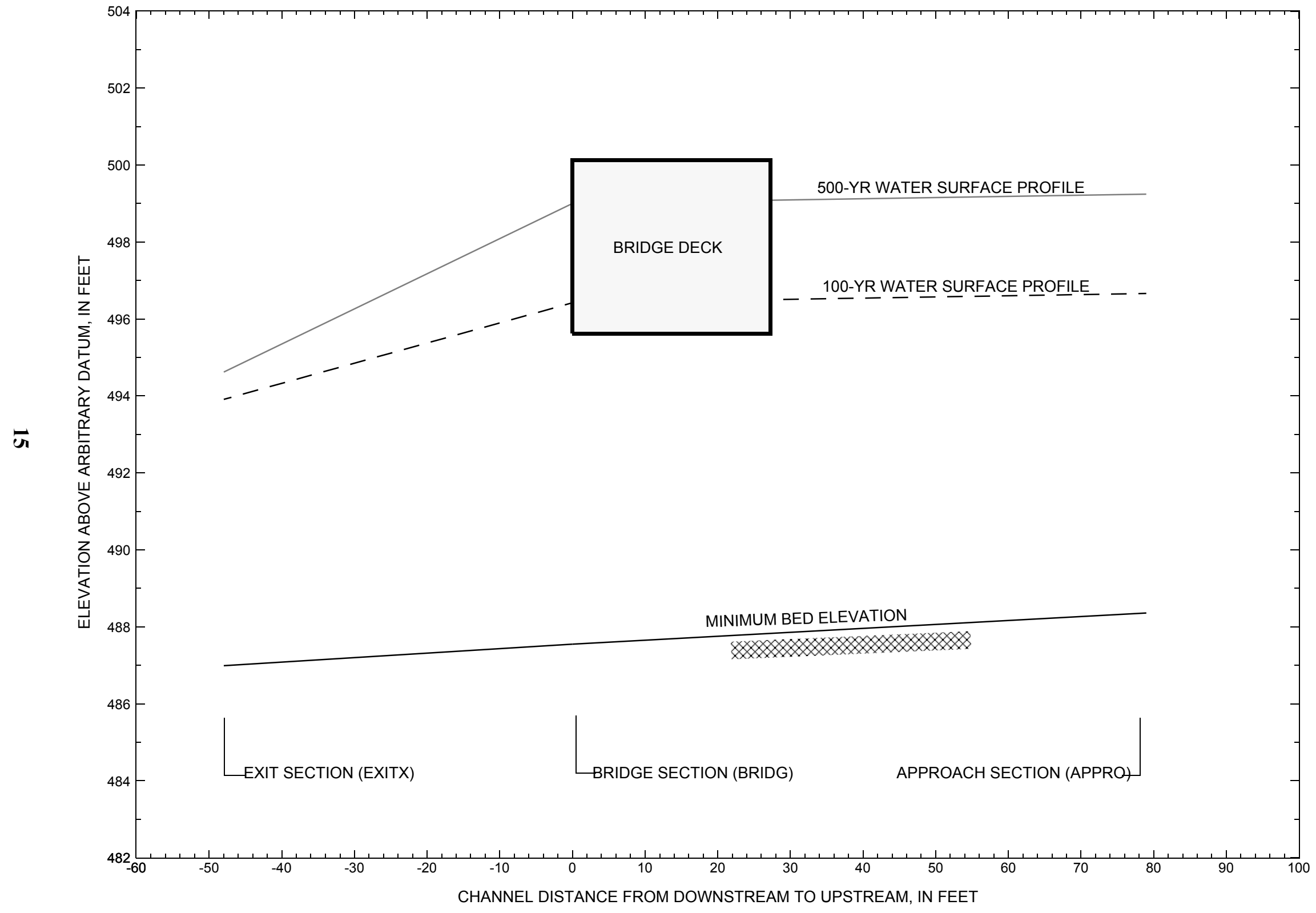

Figure 7. Water-surface profiles for the 100- and 500-yr discharges at structure POMFTH00010017 on Town Highway 1, crossing Mill Brook, Pomfret, Vermont. 


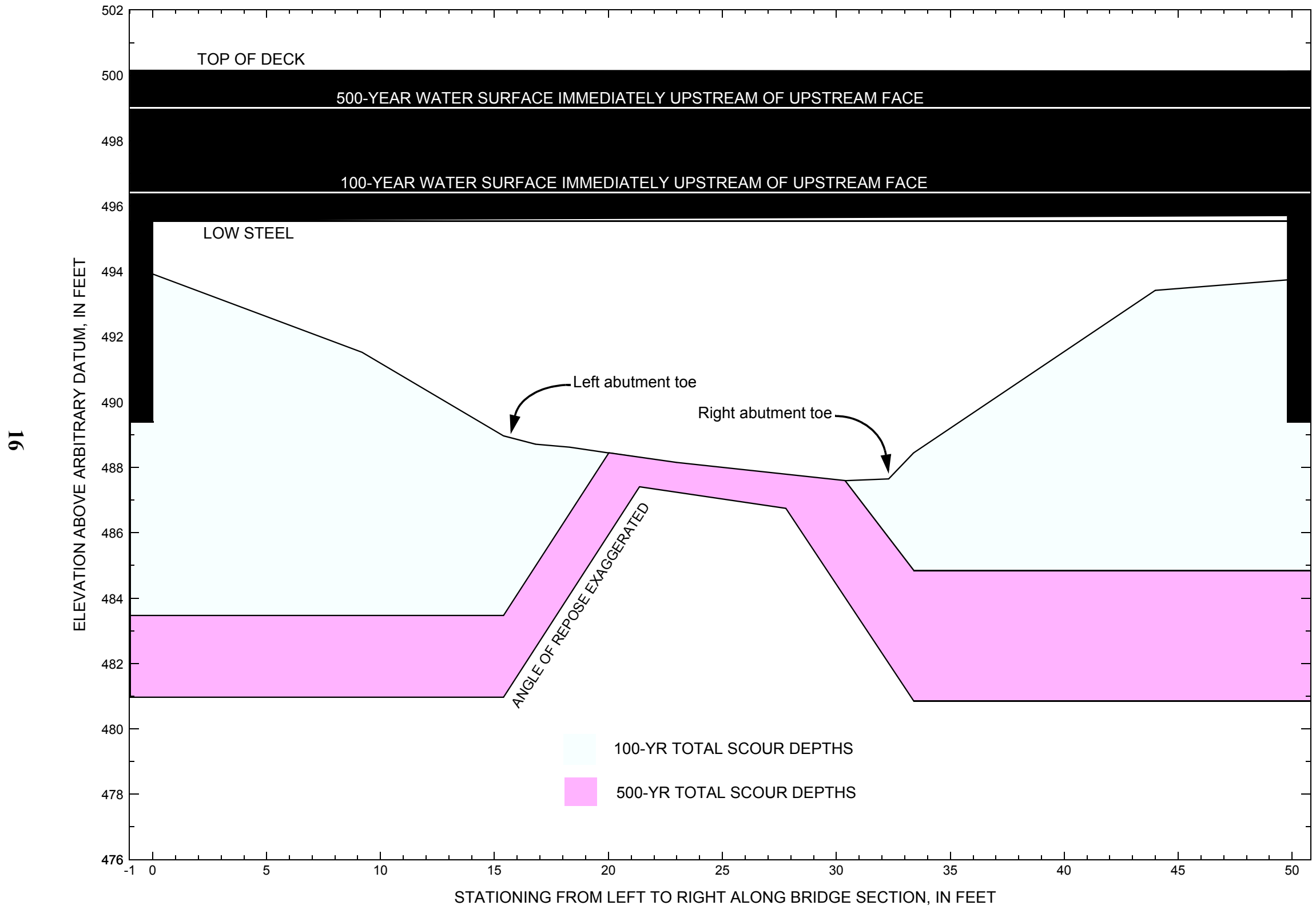

Figure 8. Scour elevations for the 100-yr and 500-yr discharges at structure POMFTH00010017 on Town Highway 1, crossing Mill Brook, Pomfret, Vermont. 
Table 1. Remaining footing/pile depth at abutments for the 100-year discharge at structure POMFTH00010017 on Town Highway 1, crossing Mill Brook, Pomfret, Vermont. [VTAOT, Vermont Agency of Transportation; --,no data]

\begin{tabular}{|c|c|c|c|c|c|c|c|c|c|c|c|}
\hline Description & Station ${ }^{1}$ & $\begin{array}{l}\text { VTAOT } \\
\text { minimum } \\
\text { low-chord } \\
\text { elevation } \\
\text { (feet) }\end{array}$ & $\begin{array}{c}\text { Surveyed } \\
\text { bridge seat } \\
\text { elevation } \\
\text { (feet) }\end{array}$ & $\begin{array}{c}\text { Bottom of } \\
\text { footing } \\
\text { elevation } \\
\text { (feet) }\end{array}$ & $\begin{array}{c}\text { Channel } \\
\text { elevation at } \\
\text { abutment/ } \\
\text { pier }^{2} \\
\text { (feet) }\end{array}$ & $\begin{array}{l}\text { Contraction } \\
\text { scour depth } \\
\text { (feet) }\end{array}$ & $\begin{array}{l}\text { Abutment } \\
\text { scour } \\
\text { depth } \\
\text { (feet) }\end{array}$ & $\begin{array}{l}\text { Pier } \\
\text { scour } \\
\text { depth } \\
\text { (feet) }\end{array}$ & $\begin{array}{l}\text { Depth of } \\
\text { total scour } \\
\text { (feet) }\end{array}$ & $\begin{array}{c}\text { Elevation of } \\
\text { scour }^{2} \\
\text { (feet) }\end{array}$ & $\begin{array}{c}\text { Remaining } \\
\text { footing/pile } \\
\text { depth } \\
\text { (feet) }\end{array}$ \\
\hline \multicolumn{12}{|c|}{100 -yr. discharge is 1,670 cubic-feet per second } \\
\hline Left abutment & 0.0 & 191.8 & 495.5 & 489.4 & 493.9 & -- & -- & -- & -- & -- & -5.9 \\
\hline Left abutment toe & 15.4 & -- & -- & -- & 489.0 & 0.0 & 5.5 & -- & 5.5 & 483.5 & -- \\
\hline Right abutment toe & 33.4 & -- & -- & -- & 488.4 & 0.0 & 3.6 & -- & 3.6 & 484.8 & -- \\
\hline Right abutment & 49.8 & 192.1 & 495.7 & 489.4 & 493.7 & -- & -- & -- & -- & -- & -4.6 \\
\hline
\end{tabular}

1.Measured along the face of the most constricting side of the bridge.

2.Arbitrary datum for this study.

Table 2. Remaining footing/pile depth at abutments for the 500-year discharge at structure POMFTH00010017 on Town Highway 1, crossing Mill Brook, Pomfret, Vermont. [VTAOT, Vermont Agency of Transportation; --, no data]

\begin{tabular}{|c|c|c|c|c|c|c|c|c|c|c|c|}
\hline Description & Station $^{1}$ & $\begin{array}{l}\text { VTAOT } \\
\text { minimum } \\
\text { low-chord } \\
\text { elevation } \\
\text { (feet) }\end{array}$ & $\begin{array}{c}\text { Surveyed } \\
\text { bridge seat } \\
\text { elevation }{ }^{2} \\
\text { (feet) }\end{array}$ & $\begin{array}{c}\text { Bottom of } \\
\text { footing } \\
\text { elevation }{ }^{2} \\
\text { (feet) }\end{array}$ & $\begin{array}{c}\text { Channel } \\
\text { elevation at } \\
\text { abutment/ } \\
\text { pier }^{2} \\
\text { (feet) }\end{array}$ & $\begin{array}{l}\text { Contraction } \\
\text { scour depth } \\
\text { (feet) }\end{array}$ & $\begin{array}{l}\text { Abutment } \\
\text { scour } \\
\text { depth } \\
\text { (feet) }\end{array}$ & $\begin{array}{l}\text { Pier } \\
\text { scour } \\
\text { depth } \\
\text { (feet) }\end{array}$ & $\begin{array}{l}\text { Depth of } \\
\text { total scour } \\
\text { (feet) }\end{array}$ & $\begin{array}{c}\text { Elevation of } \\
\text { scour }^{2} \\
\text { (feet) }\end{array}$ & $\begin{array}{c}\text { Remaining } \\
\text { footing/pile } \\
\text { depth } \\
\text { (feet) }\end{array}$ \\
\hline \multicolumn{12}{|c|}{500 -yr. discharge is 2,450 cubic-feet per second } \\
\hline Left abutment & 0.0 & 191.8 & 495.5 & 489.4 & 493.9 & -- & -- & -- & -- & -- & -8.4 \\
\hline Left abutment toe & 15.4 & -- & -- & -- & 489.0 & 0.9 & 7.1 & -- & 8.0 & 481.0 & -- \\
\hline Right abutment toe & 33.4 & -- & -- & -- & 488.4 & 0.9 & 6.7 & -- & 7.6 & 480.8 & -- \\
\hline Right abutment & 49.8 & 192.1 & 495.7 & 489.4 & 493.7 & -- & -- & -- & -- & -- & -8.6 \\
\hline
\end{tabular}

1.Measured along the face of the most constricting side of the bridge.

2.Arbitrary datum for this study. 


\section{SELECTED REFERENCES}

Arcement, G.J., Jr., and Schneider, V.R., 1989, Guide for selecting Manning's roughness coefficients for natural channels and flood plains: U.S. Geological Survey Water-Supply Paper 2339, 38 p.

Barnes, H.H., Jr., 1967, Roughness characteristics of natural channels: U.S. Geological Survey Water-Supply Paper 1849,213 p.

Benson, M. A., 1962, Factors Influencing the Occurrence of Floods in a Humid Region of Diverse Terrain: U.S. Geological Survey WaterSupply Paper 1580-B, 64 p.

Brown, S.A. and Clyde, E.S., 1989, Design of riprap revetment: Federal Highway Administration Hydraulic Engineering Circular No. 11, Publication FHWA-IP-89-016, 156 p.

Federal Highway Administration, 1983, Runoff estimates for small watersheds and development of sound design: Federal Highway Administration Report FHWA-RD-77-158

Froehlich, D.C., 1989, Local scour at bridge abutments in Ports, M.A., ed., Hydraulic Engineering--Proceedings of the 1989 National Conference on Hydraulic Engineering: New York, American Society of Civil Engineers, p. 13-18.

Hayes, D.C.,1993, Site selection and collection of bridge-scour data in Delaware, Maryland, and Virginia: U.S. Geological Survey WaterResources Investigation Report 93-4017, 23 p.

Johnson, C.G. and Tasker, G.D.,1974, Progress report on flood magnitude and frequency of Vermont streams: U.S. Geological Survey OpenFile Report 74-130, 37 p.

Lagasse, P.F., Schall, J.D., Johnson, F., Richardson, E.V., Chang, F., 1995, Stream Stability at Highway Structures: Federal Highway Administration Hydraulic Engineering Circular No. 20, Publication FHWA-IP-90-014, 144 p.

Laursen, E.M., 1960, Scour at bridge crossings: Journal of the Hydraulics Division, American Society of Civil Engineers, v. 86, no. HY2, p. 39-53.

Potter, W. D., 1957, Peak rates of runoff in the New England Hill and Lowland area, Bureau of Public Roads

Richardson, E.V. and Davis, S.R., 1995, Evaluating scour at bridges: Federal Highway Administration Hydraulic Engineering Circular No. 18, Publication FHWA-IP-90-017, 204 p.

Richardson, E.V., Simons, D.B., and Julien, P.Y., 1990, Highways in the river environment: Federal Highway Administration Publication FHWA-HI-90-016.

Ritter, D.F., 1984, Process Geomorphology: W.C. Brown Co., Debuque, Iowa, 603 p.

Shearman, J.O., 1990, User's manual for WSPRO--a computer model for water surface profile computations: Federal Highway Administration Publication FHWA-IP-89-027, 187 p.

Shearman, J.O., Kirby, W.H., Schneider, V.R., and Flippo, H.N., 1986, Bridge waterways analysis model; research report: Federal Highway Administration Publication FHWA-RD-86-108, 112 p.

Talbot, A.N., 1887, The determination of water-way for bridges and culverts.

U.S. Department of Transportation, 1993, Stream stability and scour at highway bridges, Participant Workbook: Federal Highway Administration Publication FHWA HI-91-011.

U.S. Geological Survey, 1959, Quechee, Vermont 7.5 Minute Series quadrangle map: U.S. Geological Survey Topographic Maps, Aerial photography, 1956, Photo-revision, 1988; Contour interval 20 feet, Scale 1:24,000. 


\section{APPENDIX A: \\ WSPRO INPUT FILE}




\section{WSPRO INPUT FILE}

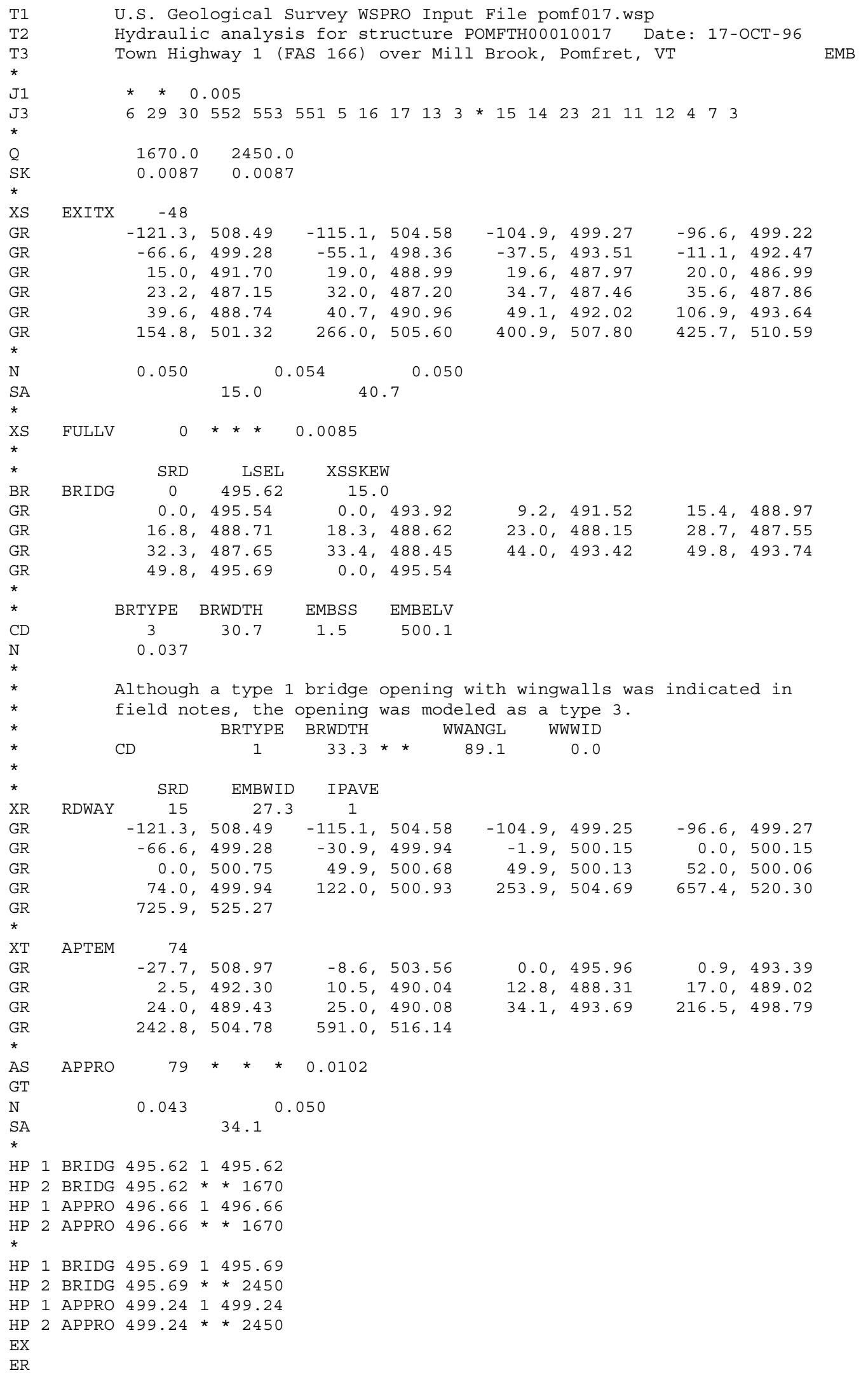




\section{APPENDIX B: \\ WSPRO OUTPUT FILE}


WSPRO OUTPUT FILE

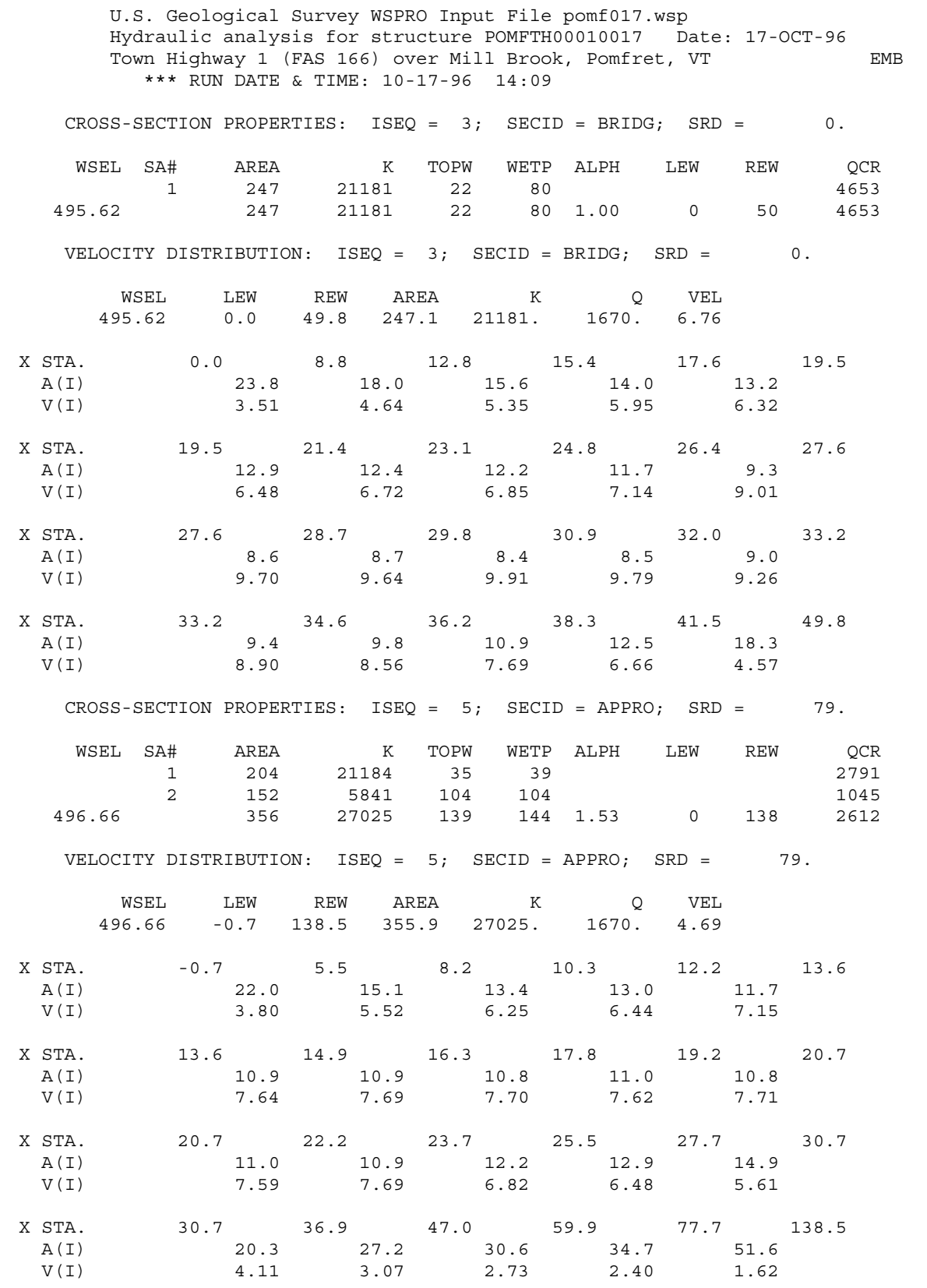


WSPRO OUTPUT FILE (continued)

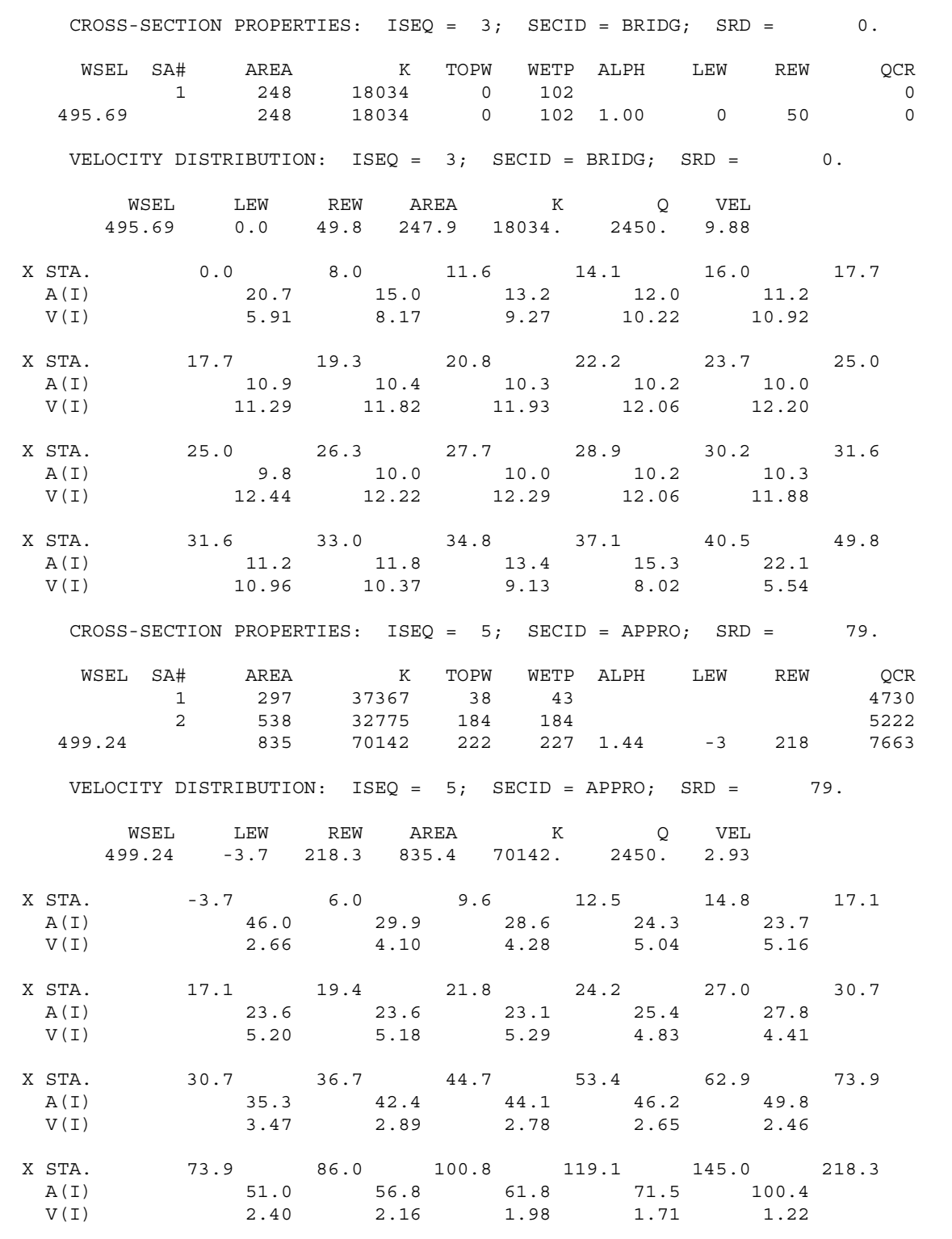


WSPRO OUTPUT FILE (continued)

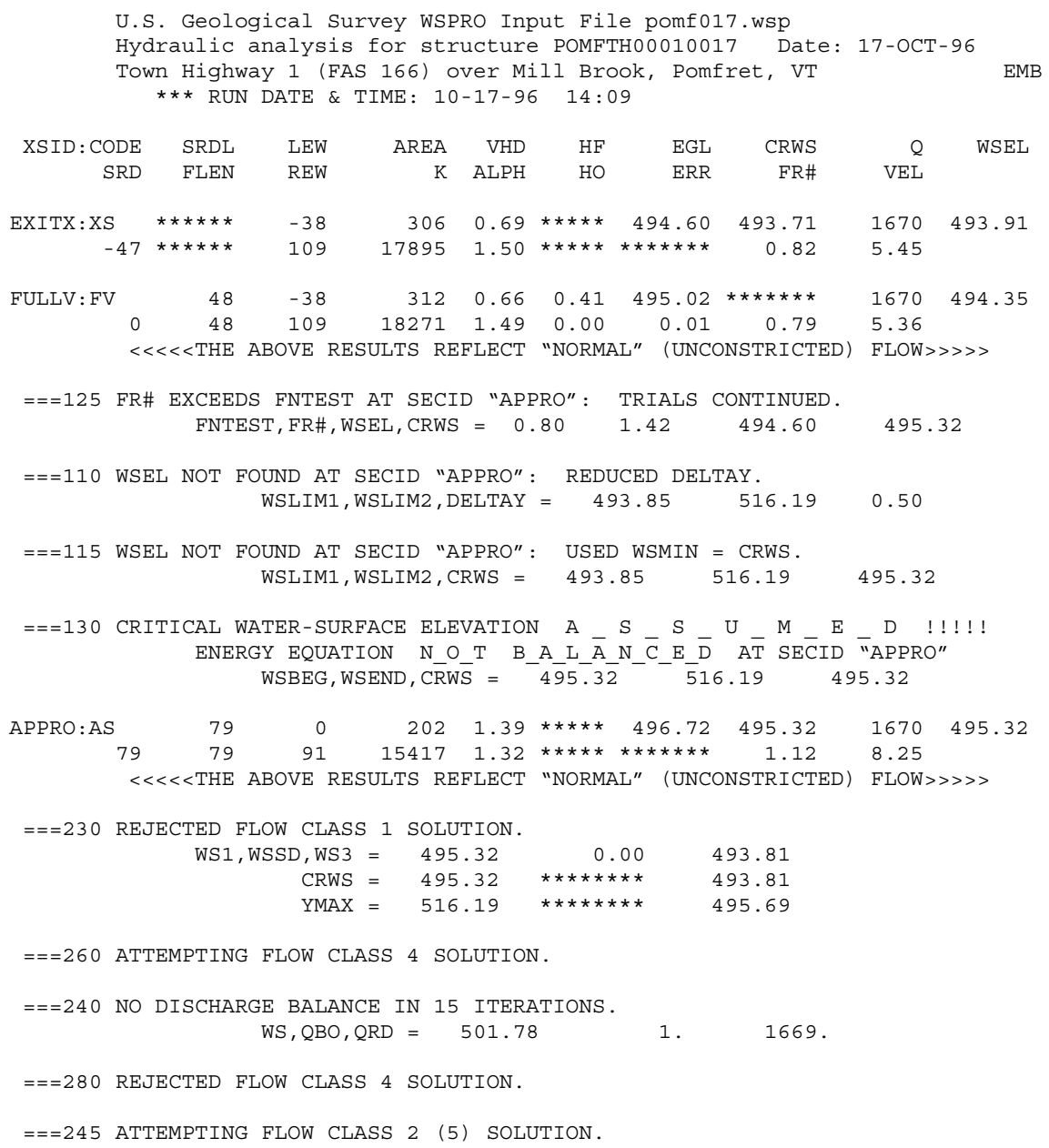

FIRST USER DEFINED TABLE.

\begin{tabular}{|c|c|c|c|c|c|c|c|c|}
\hline XSID : CODE & SRD & LEW & REW & $Q$ & K & AREA & VEL & WSEL \\
\hline EXITX : XS & -48 & -39 & 109. & 1670 . & 17895. & 306. & 5.45 & 493.91 \\
\hline FULLV : FV & 0 . & -39 & 109. & 1670. & 18271. & 312 . & 5.36 & 494.35 \\
\hline BRIDG : BR & 0 . & 0 . & 50. & 1663. & 21181 . & 247 & 6.73 & 495.62 \\
\hline RDWAY : RG & \multicolumn{3}{|c|}{ 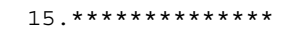 } & \multicolumn{3}{|c|}{$0 . * * * * * * * * * * * * * * * * * *$} & \multicolumn{2}{|c|}{$1.00 * * \star * \star * * * *$} \\
\hline APPRO : AS & 79. & -1 & 139. & 1670. & 27075 . & 357. & 4.68 & 496.66 \\
\hline XSID : CODE & XLKQ & $\mathrm{XRKQ}$ & & & & & & \\
\hline PPRO : AS & & & & & & & & \\
\hline
\end{tabular}




\section{WSPRO OUTPUT FILE (continued)}

SECOND USER DEFINED TABLE.

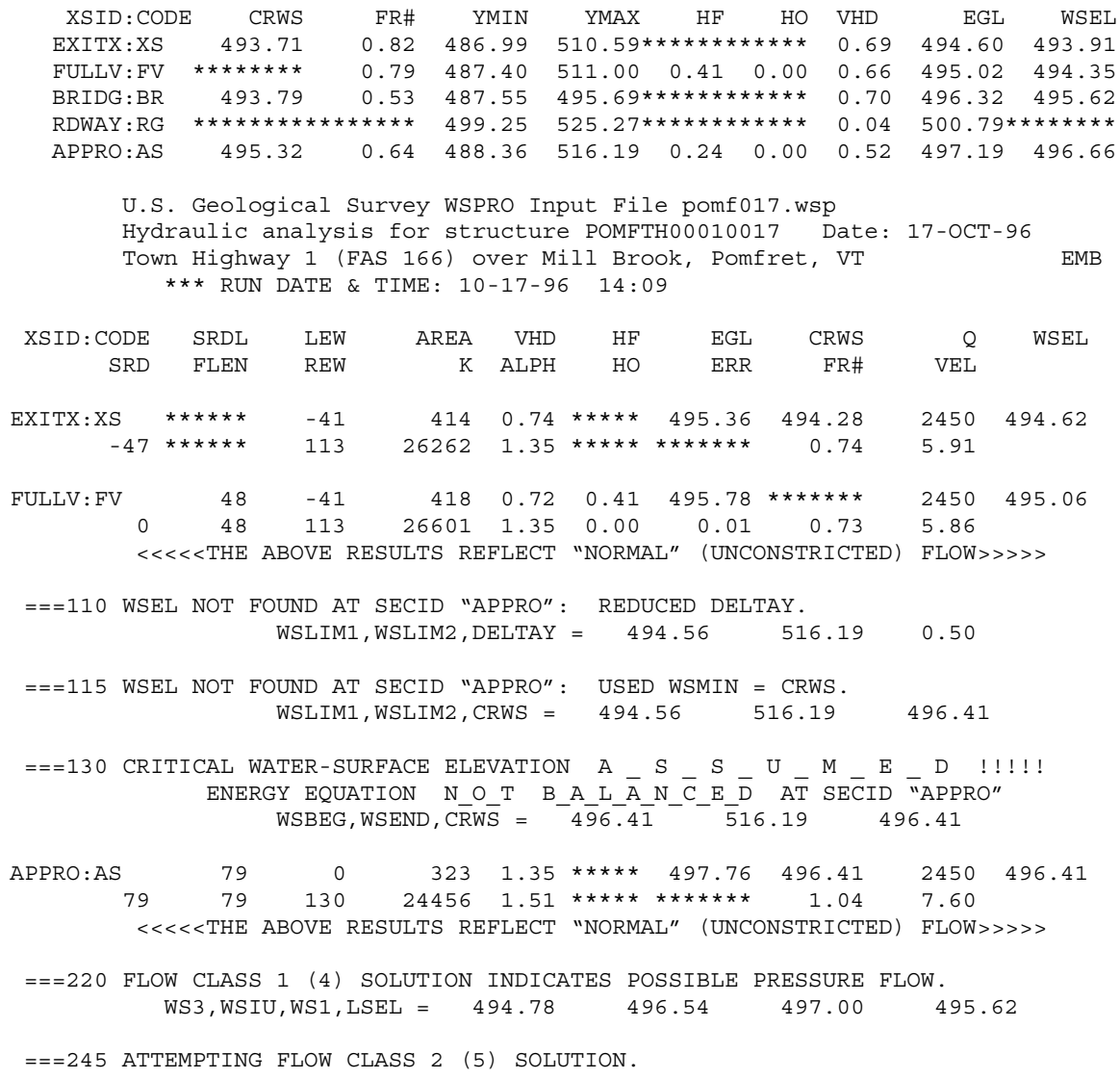

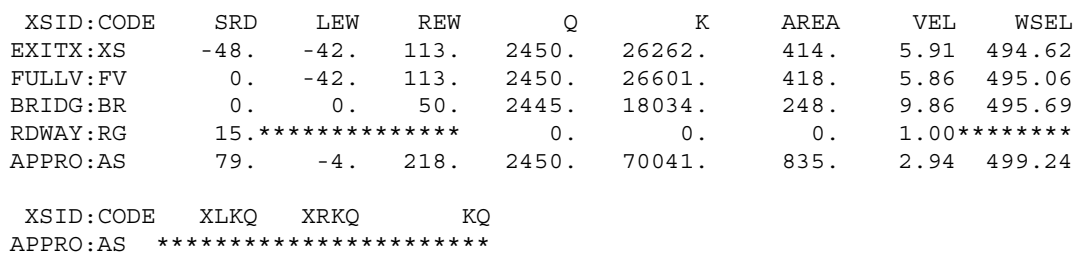


WSPRO OUTPUT FILE (continued)

SECOND USER DEFINED TABLE.

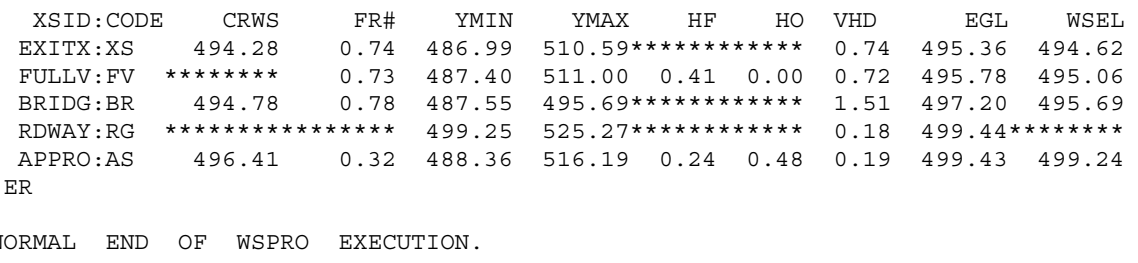




\section{APPENDIX C:}

\section{BED-MATERIAL PARTICAL-SIZE DISTRIBUTION}




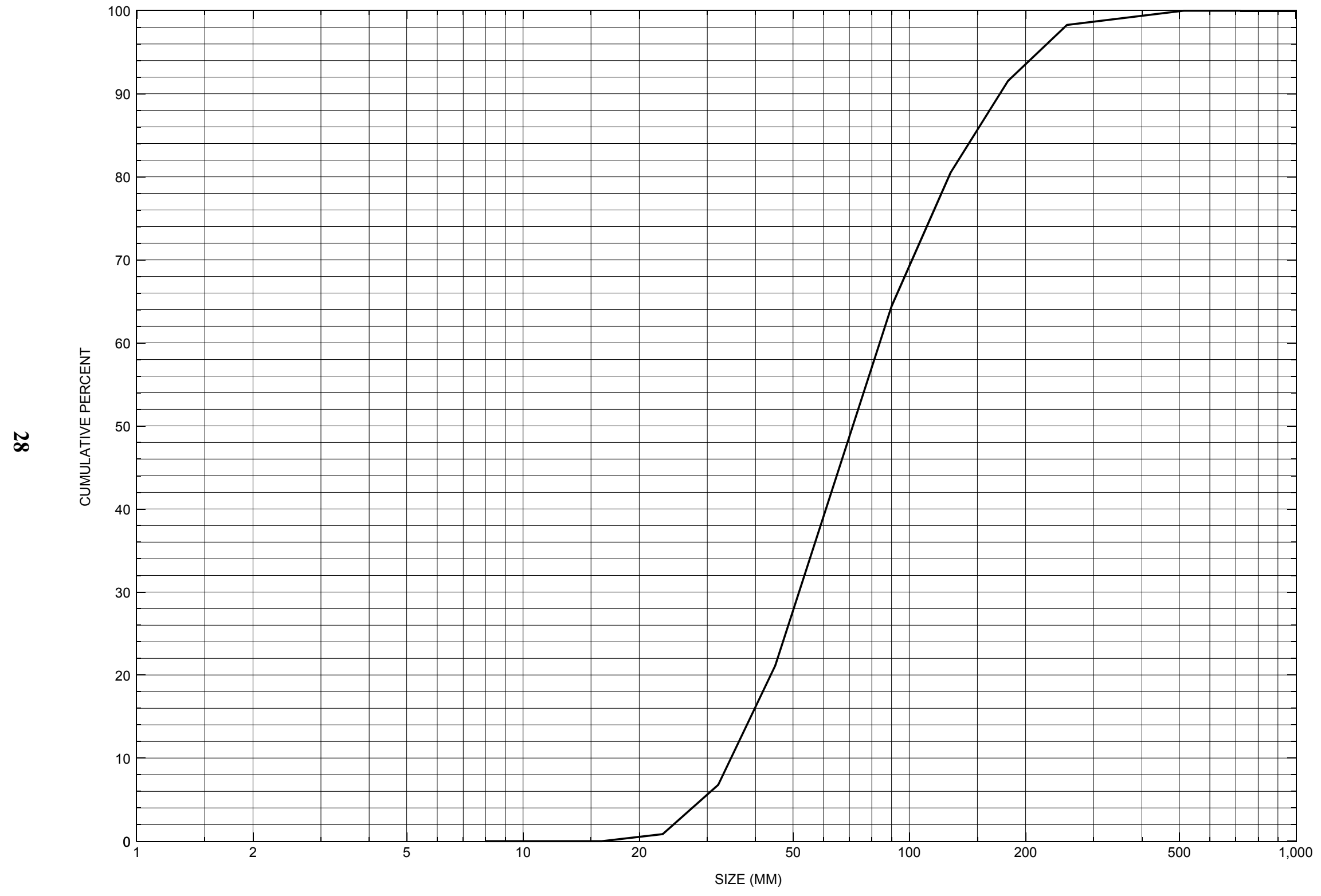

Appendix C. Bed material particle-size distribution for a pebble count in the channel approach of structure POMFTH00010017, in Pomfret, Vermont. 


\section{APPENDIX D: \\ HISTORICAL DATA FORM}




\section{Structure Number POMFTH00010017}

\section{General Location Descriptive}

Data collected by (First Initial, Full last name) M. IVANOFF

Date $(M M / D D / Y Y) \_\mathbf{0 8} / \underline{\mathbf{2 3}} / \underline{\mathbf{9 4}}$

Highway District Number (I - 2; nn) 04

Town (FIPS place code; I - 4; nnnnn) $\mathbf{5 6 3 5 0}$

Waterway (I - 6) MILL BROOK

Route Number TH01

Topographic Map Quechee

Latitude (I - 16; nnnn.n) $\mathbf{4 3 4 3 5}$
County (FIPS county code; I - 3; nnn)

Mile marker (I - 11; nnn.nnn) $\mathbf{0 0 7 8 6 0}$

Road Name (I - 7): -

Vicinity (I - 9) 3.3 MI W JCT. VT.14

Hydrologic Unit Code: $\mathbf{0 1 0 8 0 1 0 6}$

Longitude (i - 17; nnnnn.n) $\mathbf{7 2 2 8 0}$

\section{Select Federal Inventory Codes}

FHWA Structure Number $(I$ - 8) $\mathbf{2 0 0 1 6 6 0 0 1 7 1 4 1 3}$

Maintenance responsibility $(I-21 ; n n) \quad \mathbf{0 3}$

Year built (I - 27; YYYY) 1948

Average daily traffic, ADT (I - 29; nnnnnn) 000460

Year of ADT (I - 30; YY) $\mathbf{9 1}$

Opening skew to Roadway $(I-34 ; n n) \quad 15$

Operational status $(I-41 ; X)$ A

Structure type (I - 43; nnn) $\mathbf{3 0 2}$

Approach span structure type $(I-44 ; n n n) \quad \mathbf{0 0 0}$

Number of spans (I - 45; nnn) $\mathbf{0 0 1}$

Number of approach spans (I - 46; nnnn) $\mathbf{0 0 0 0}$ Comments:

This bridge is on the federal aid system, route 166. Structural inspection report of 5/5/94 indicates substructure has a vertical crack in left abutment at BM\#2. Minor cracking on the back- and wingwalls. Heavy stone fill (rip rap) is noted at the abutments. No scour is noted and only minor embankment erosion. Channel alignment is straight through the bridge crossing. Status of drift/vegetation and riprap are not addressed on report.
Maximum span length (I - 48; nnnn) $\underline{\mathbf{0 0 5 2}}$

Structure length (I - 49; nnnnnn) $\underline{000054}$

Deck Width (I - 52; nn.n) 273

Channel \& Protection $(I-61 ; n) \underline{\mathbf{8}}$

Waterway adequacy $(I-71 ; n) \underline{8}$

Underwater Inspection Frequency $(I-92 B ; X Y Y) \_$N

Year Reconstructed (I - 106) $\mathbf{0 0 0 0}$

Clear span (nnn.n ft) _ _

Vertical clearance from streambed (nnn.n ft) $\underline{\mathbf{0 0 7 . 0}}$

Waterway of full opening $\left(n n n . n \mathrm{ft}^{2}\right)$ - 


\section{Bridge Hydrologic Data}

Is there hydrologic data available? $\underline{\mathbf{N}}$ if No, type ctrl-n $h \quad$ VTAOT Drainage area $\left(m i^{2}\right)$ : -

Terrain character:

Stream character \& type: -

Streambed material:

Discharge Data (cfs):

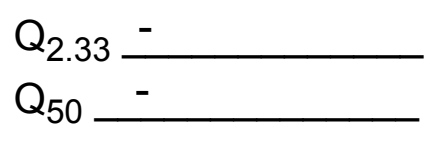

Record flood date $(M M / D D / Y Y):-{ }^{\prime}-$
Estimated Discharge $(c f s):-$

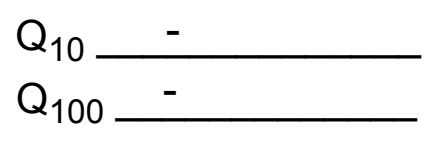

$Q_{25}-$
$Q_{500}-$

Water surface elevation $(f t)$ : $(\mathrm{ft} / \mathrm{s}):$

Ice conditions (Heavy, Moderate, Light) : -

Debris (Heavy, Moderate, Light):

The stage increases to maximum highwater elevation (Rapidly, Not rapidly):

The stream response is (Flashy, Not flashy):

Describe any significant site conditions upstream or downstream that may influence the stream's stage: -

Watershed storage area (in percent): $\%$

The watershed storage area is: - _ (1-mainly at the headwaters; 2- uniformly distributed; 3-immediatly upstream oi the site)

Water Surface Elevation Estimates for Existing Structure:

\begin{tabular}{|l|l|l|l|l|l|}
\hline Peak discharge frequency & $Q_{2.33}$ & $Q_{10}$ & $Q_{25}$ & $Q_{50}$ & $Q_{100}$ \\
Water surface elevation (ft)) & - & - & - & - & - \\
Velocity (ft/sec) & - & - & - & - & - \\
\hline
\end{tabular}

Long term stream bed changes: -

Is the roadway overtopped below the $\mathrm{Q}_{100}$ ? (Yes, No, Unknown): $\mathbf{U}$ Frequency: Relief Elevation $(f t)$ : Discharge over roadway at $Q_{100}\left(f^{3} / \mathrm{sec}\right)$ :

Are there other structures nearby? (Yes, No, Unknown): $\underline{\mathbf{U}}$ Upstream distance (miles): Town: If No or Unknown, type ctrl-n os Highway No. : $\underline{\mathbf{U}}$ Structure No. : Year Built:

Clear span (ft): Clear Height $(f t)$ : Full Waterway $\left(f^{2}\right)$ : 
Downstream distance (miles): Town: Year Built:

Highway No. : Structure No. : Structure Type:

Clear span $(f t):$ Clear Height $(f t)$ : Full Waterway $\left(f t^{2}\right)$ :

Comments:

\section{USGS Watershed Data}

Watershed Hydrographic Data

Drainage area $(D A)$

8.11 $\mathrm{mi}^{2}$

Watershed storage (ST)

Bridge site elevation 715 Main channel length 5.22 $\mathrm{ft}$ $\%$

Lake and pond area $\mathrm{mi}^{2}$ $10 \%$ channel length elevation $\mathbf{7 6 0}$ $\mathrm{ft} \quad 85 \%$ channel length elevation $\mathrm{ft}$

Main channel slope $(S)$

(S) 122.68 $\mathrm{ft} / \mathrm{mi}$

Watershed Precipitation Data

Average site precipitation in

Average headwater precipitation in

Maximum 2yr-24hr precipitation event $(124,2)$ in

Average seasonal snowfall (Sn) $\mathrm{ft}$ 


\section{Bridge Plan Data}

Are plans available? $\underline{Y}$ If no, type ctrl-n pl Date issued for construction (MM/YYYY): 06 / 1947 Project Number SA 25-1944 Minimum channel bed elevation: 184.0 Low superstructure elevation: USLAB 191.83 DSLAB 191.85 USRAB 192.15 DSRAB $\underline{192.13}$ Benchmark location description:

BM\#2 in a 14 inch elm in area of downstream left wingwall near top of the left bank of the channel, elevation 187.32.

Reference Point (MSL, Arbitrary, Other): Arbitrary $\quad$ Datum (NAD27, NAD83, Other): Foundation Type: 1 (1-Spreadfooting; 2-Pile; 3- Gravity; 4-Unknown)

If 1: Footing Thickness $\underline{\mathbf{2 . 0}}$ Footing bottom elevation: $\underline{\mathbf{1 8 6 . 0}}$

If 2: Pile Type: ___ (1-Wood; 2-Steel or metal; 3-Concrete) Approximate pile driven length: -

If 3: Footing bottom elevation: -

Is boring information available? $\mathbf{N}$ If no, type ctrl-n bi Number of borings taken: -

Foundation Material Type: $\mathbf{3}$ (1-regolith, 2-bedrock, 3-unknown)

Briefly describe material at foundation bottom elevation or around piles:

NO FOUNDATION MATERIAL INFORMATION

Comments:

Riprap sloping abutment indicated as constructed at a 1.5 to 1 slope in front of abutment backwalls. 


\section{Cross-sectional Data}

Is cross-sectional data available? $\underline{\mathbf{Y}}$ If no, type ctrl-n xs

Source (FEMA, VTAOT, Other)? VTAOT

Comments: Cross sections were available for the upstream and downstream face of the bridge, but elevations were not retrieved properly. Therefore, they were omitted.

\begin{tabular}{|l|l|l|l|l|l|l|l|l|l|l|l|}
\hline Station & & & & & & & & & & & \\
\hline Feature & & & & & & & & & & & \\
\hline $\begin{array}{l}\text { Low cord } \\
\text { elevation }\end{array}$ & & & & & & & & & & & \\
\hline $\begin{array}{l}\text { Bed } \\
\text { elevation }\end{array}$ & & & & & & & & & & & \\
\hline $\begin{array}{l}\text { Low cord to } \\
\text { bed length }\end{array}$ & & & & & & & & & & & \\
\hline Station & & & & & & & & & & & \\
\hline Feature & & & & & & & & & & & \\
\hline $\begin{array}{l}\text { Low cord } \\
\text { elevation }\end{array}$ & & & & & & & & & & & \\
\hline $\begin{array}{l}\text { Bed } \\
\text { elevation }\end{array}$ & & & & & & & & & & & \\
\hline $\begin{array}{l}\text { Low cord to } \\
\text { bed length }\end{array}$ & & & & & & & & & & & \\
\hline
\end{tabular}

Source (FEMA, VTAOT, Other)?

Comments:

\begin{tabular}{|l|l|l|l|l|l|l|l|l|l|l|l|}
\hline Station & & & & & & & & & & & \\
\hline Feature & & & & & & & & & & & \\
\hline $\begin{array}{l}\text { Low cord } \\
\text { elevation }\end{array}$ & & & & & & & & & & & \\
\hline $\begin{array}{l}\text { Bed } \\
\text { elevation }\end{array}$ & & & & & & & & & & & \\
\hline $\begin{array}{l}\text { Low cord to } \\
\text { bed length }\end{array}$ & & & & & & & & & & & \\
\hline Station & & & & & & & & & & & \\
\hline Feature & & & & & & & & & & & \\
\hline $\begin{array}{l}\text { Low cord } \\
\text { elevation }\end{array}$ & & & & & & & & & & & \\
\hline $\begin{array}{l}\text { Bed } \\
\text { elevation }\end{array}$ & & & & & & & & & & & \\
\hline $\begin{array}{l}\text { Low cord to } \\
\text { bed length }\end{array}$ & & & & & & & & & & & \\
\hline
\end{tabular}




\section{APPENDIX E: \\ LEVEL I DATA FORM}


U. S. Geological Survey

Bridge Field Data Collection and Processing Form

Qa/Qc Check by: EW

Date: $\mathbf{8 / 1 2 / 9 6}$

\section{Structure Number}

POMFTH00010017

\section{A. General Location Descriptive}

1. Data collected by (First Initial, Full last name) $\quad$ R Hammond

2. Highway District Number 04

County Windsor (027)

Waterway (I - 6) Mill Brook

Route Number TH01

3. Descriptive comments:

Located 3.3 miles west from the intersection of VT 14 and TH 1. Also located 0.7 miles downstream of North Pomfret.
Mile marker 007860

Town Pomfret (56350)

Road Name Pomfret Road

Hydrologic Unit Code: 01080106

Reviewd by: EMB Date: $12 / 9 / 96$

\section{B. Bridge Deck Observations}

\section{Surface cover... LBUS 4 \\ RBUS 4 \\ LBDS 4 \\ RBDS 4 \\ Overall 4}

(2b us,ds,lb,rb: 1- Urban; 2- Suburban; 3- Row crops; 4- Pasture; 5- Shrub- and brushland; 6- Forest; 7- Wetland)
5. Ambient water surface...US $\underline{2}$
UB 2
DS $\underline{2}$
(1- pool; 2- riffle)

6. Bridge structure type 1 (1- single span; 2- multiple span; 3- single arch; 4- multiple arch; 5-cylindrical culvert; 6- box culvert; or 7- other)
7. Bridge length $\mathbf{5 4}$
(feet)
Span length $\underline{\mathbf{5 2}}$
(feet)
Bridge width 27.3 (feet)

\section{Road approach to bridge:}
8. LB 0
RB 0
( 0 even, 1- lower, 2- higher)
9. LB
RB 1
(1-Paved, 2- Not paved)

10. Embankment slope (run / rise in feet / foot)

US left

US right --

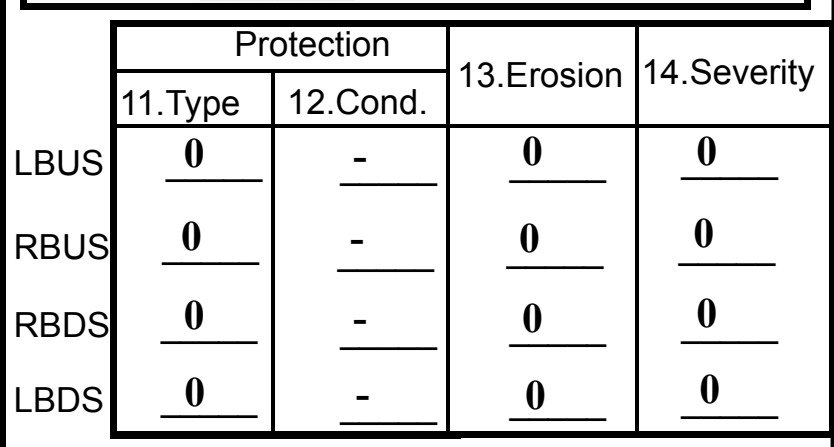

Bank protection types: 0- none; 1- < 12 inches;

2- < 36 inches; 3- < 48 inches;

4- < 60 inches; 5- wall / artificial levee

Bank protection conditions: 1- good; 2- slumped;

3- eroded; 4- failed

Erosion: 0 - none; 1- channel erosion; 2 -

road wash; 3- both; 4- other

Erosion Severity: 0 - none; 1- slight; 2- moderate; 3- severe

\section{Channel approach to bridge (BF):}

15. Angle of approach: $\mathbf{5}$

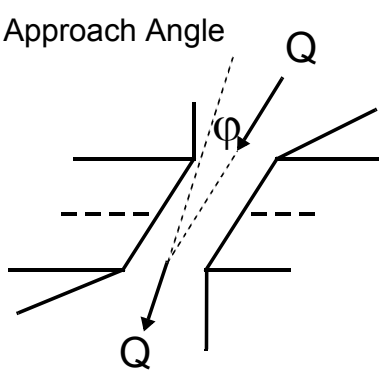

17. Channel impact zone 1:

Where? LB (LB, RB)

Range? 90 feet US

Channel impact zone 2:

Where? (LB, RB)

Range? feet (US, UB, DS) to feet

16. Bridge skew: 15 Bridge Skew Angle

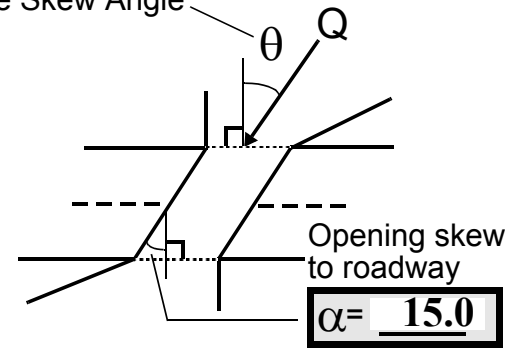

\section{Exist? $\mathbf{Y}(Y$ or $N)$}

Severity $\underline{3}$

(US, UB, DS) to $\underline{\mathbf{6 4}}$ feet $\underline{\mathbf{U S}}$

Exist? $\underline{\mathbf{N}}(\mathrm{Y}$ or $N)$

Severity

Impact Severity: 0- none to very slight; 1- Slight; 2- Moderate; 3- Severe 
18. Bridge Type: 1a

1a- Vertical abutments with wingwalls

1 b- Vertical abutments without wingwalls

2- Vertical abutments and wingwalls, sloping embankment Wingwalls perpendicular to abut. face

3- Spill through abutments

4- Sloping embankment, vertical wingwalls and abutments

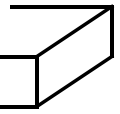

1a with wingwalls

Wingwall angle less than $90^{\circ}$.

19. Bridge Deck Comments (surface cover variations, measured bridge and span lengths, bridge type variations, approach overflow width, etc.)

7: Measured length (from outside of abutment to outside of abutment) is 54.2 feet. Clear span (from inside of abutment to inside of abutment) is $\mathbf{2 4 . 1}$ feet. The bridge width from each inside curbs is 24.1 feet, and the width from each outside curbs is $\mathbf{2 7 . 0}$ feet.

Recent (within at least the last month) flows upstream of the bridge have existed over the right bank and onto the flood plain. The water depth on the flood plain was approximately 0.5 feet.

17: Right angle change in stream channel, 90 degrees with respect to the bridge.

\section{Upstream Channel Assessment}

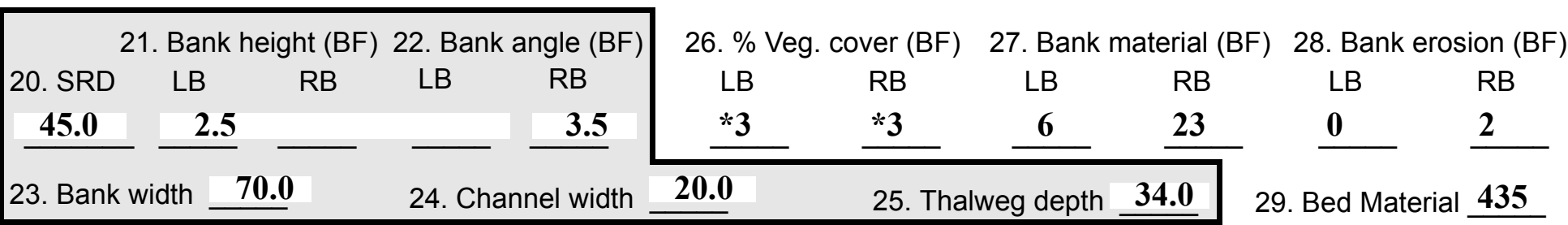

\section{0 .Bank protection type:}

LB 2

RB 0

31. Bank protection condition:

LB 1

RB -

SRD - Section ref. dist. to US face \% Vegetation (Veg) cover: 1- 0 to 25\%; 2- 26 to 50\%; 3- 51 to $75 \%$; 4- 76 to $100 \%$

Bed and bank Material: 0- organics; 1- silt / clay, < 1/16mm; 2- sand, 1/16 - 2mm; 3- gravel, 2 - 64mm;

4- cobble, 64 - 256mm; 5- boulder, > 256mm; 6- bedrock; 7- manmade

Bank Erosion: 0- not evident; 1- light fluvial; 2- moderate fluvial; 3- heavy fluvial / mass wasting

Bank protection types: 0- absent; 1- < 12 inches; 2- < 36 inches; 3- < 48 inches; 4- < 60 inches; 5- wall / artificial levee

Bank protection conditions: 1-good; 2- slumped; 3- eroded; 4- failed

32. Comments (bank material variation, minor inflows, protection extent, etc.):

26: * $0 \%$ vegetation cover from upstream bridge face to approach cross section. From approach cross section

to at least two bridge lengths upstream, the vegetation cover is $100 \%$ on both banks.

28: Bedrock is exposed on the left bank.

30: Some boulders on top of bedrock on LB.

Bend in upstream section of reach is 83 feet US of upstream bridge face.

During recent bank full flows, several trees have fallen down which has blocked main channel at 180 feet US.

In addition, a two feet in height channel bar has developed as a result of the upstream blockage. 
33.Point/Side bar present? $\mathbf{Y}$

$(Y$ or $N$. if $N$ type ctrl-n pb)34. Mid-bar distance: 15

35. Mid-bar width: 8

36. Point bar extent: $\mathbf{2 0}$ feet US

(US, UB) to 25 feet $\underline{\mathbf{D S}}$

(US, UB, DS) positioned $\mathbf{0}$

\%LB to $\mathbf{4 0}$ $\% R B$

37. Material: 43

38. Point or side bar comments (Circle Point or Side; Note additional bars, material variation, status, etc.):

Additional point bar exists on right bank 75 feet US to 62 feet US where bend exists in stream. A channel bar is also present in the center of the stream from approximately 300 feet US to 180 feet US.

39. Is a cut-bank present? $\mathbf{Y}$ ( $Y$ or if $N$ type ctrl-n $c b)$

41. Mid-bank distance: $\mathbf{2 5}$

42. Cut bank extent: $\mathbf{4 0}$

40. Where? $\mathbf{R B}$ (LB or RB)

43. Bank damage: 1

(1- eroded and/or creep; 2- slip failure; 3- block failure)

44. Cut bank comments (eg. additional cut banks, protection condition, etc.):

In addition, roots are exposed on left bank above bedrock from 60 feet US to 35 feet US.

45. Is channel scour present? $\mathbf{Y}$ ( $Y$ or if $N$ type ctrl-n cs)

47. Scour dimensions: Length $\mathbf{4 0}$ Width 7

Depth : $\mathbf{2 . 2 5}$

46. Mid-scour distance: $\underline{\mathbf{6 0}}$

48. Scour comments (eg. additional scour areas, local scouring process, etc.):

Average water depth is 0.75 feet. Channel scour extends from 80 feet US to 40 feet US.

49. Are there major confluences? $\mathbf{N}$

51. Confluence 1: Distance -

Confluence 2: Distance -

52. Enters on -

Enters on -

54. Confluence comments (eg. confluence name):

NO MAJOR CONFLUENCES
50. How many? -

53. Type(1- perennial; 2- ephemeral)

Type (1-perennial; 2- ephemeral) ( $(L B$ or $R B)$ (LB or $R B)$ (1-perennial; 2-ephemeral) 
65. Debris and Ice Is there debris accumulation?

$(Y$ or $N)$ 66. Where? $\underline{Y}$

(1- Upstream; 2- At bridge; 3- Both)

67. Debris Potential 1 (1-Low; 2-Moderate; 3- High)

68. Capture Efficiency 2

(1-Low; 2- Moderate; 3- High)

69. Is there evidence of ice build-up? 1 ( $Y$ or $N)$

Ice Blockage Potential $\underline{\mathbf{N}}$

(1- Low; 2- Moderate; 3- High)

70. Debris and Ice Comments:

1

68: Compared to channel upstream, bridge opening is rather wide. Therefore, capture efficiency is low.

69: Also, the ice blockage potential will be low.

\begin{tabular}{|l|c|c|c|c|c|c|c|c|}
\hline Abutments & $\begin{array}{c}\text { 71. Attack } \\
\angle \text { (BF) }\end{array}$ & $\begin{array}{c}72 \text {. Slope } \angle \\
\text { (Qmax) }\end{array}$ & $\begin{array}{c}\text { 73. Toe } \\
\text { loc. (BF) }\end{array}$ & $\begin{array}{c}\text { 74. Scour } \\
\text { Condition }\end{array}$ & $\begin{array}{c}75 . \text { Scour } \\
\text { depth }\end{array}$ & $\begin{array}{c}\text { 76. Exposure } \\
\text { depth }\end{array}$ & 77. Material & 78. Length \\
\hline LABUT & & $\mathbf{0}$ & $\mathbf{9 0}$ & $\mathbf{0}$ & $\mathbf{0}$ & - & - & $\mathbf{9 0 . 0}$ \\
\hline RABUT & $\mathbf{1}$ & $\mathbf{0}$ & $\mathbf{9 0}$ & & & $\mathbf{0}$ & $\mathbf{0}$ & $\mathbf{4 8 . 0}$ \\
\hline
\end{tabular}

Pushed: $L B$ or RB

Toe Location (Loc.): 0- even, 1- set back, 2- protrudes

Scour cond.: 0- not evident; 1- evident (comment); 2- footing exposed; 3-undermined footing; 4- piling exposed; 5- settled; 6- failed

Materials: 1- Concrete; 2- Stone masonry or drywall; 3- steel or metal; 4- wood

79. Abutment comments (eg. undermined penetration, unusual scour processes, debris, etc.):

80. Wingwalls:

Exist? Material? Scour Scour Exposure $\begin{aligned} & 81 . \\ & \text { Angle? Length? }\end{aligned}$ Condition? depth? depth?

USLWW:

48.0

USRWW:

DSLWW:

DSRWW: -

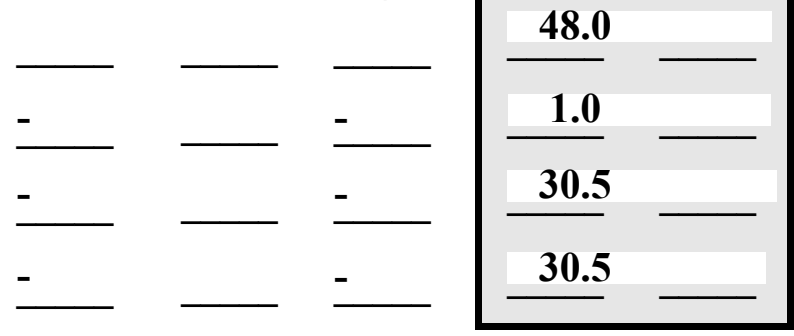

Wingwall materials: 1- Concrete; 2- Stone masonry or drywall; 3- steel or metal; 4- wood

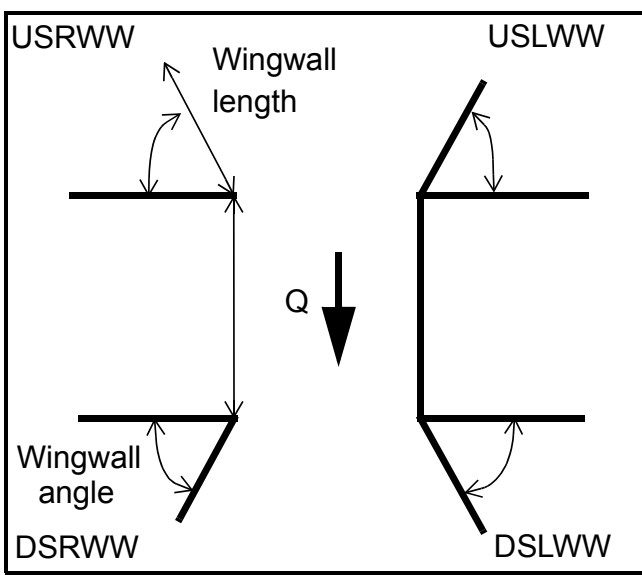

82. Bank / Bridge Protection:

\begin{tabular}{|l|l|l|l|l|l|l|l|c|}
\hline Location & USLWW & USRWW & LABUT & RABUT & LB & RB & DSLWW & DSRWW \\
\hline Type & - & - & - & - & - & - & $\mathbf{1}$ & $\mathbf{1}$ \\
\hline Condition & - & - & - & - & - & - & $\mathbf{1}$ & $\mathbf{1}$ \\
\hline Extent & - & - & - & $\mathbf{0}$ & $\mathbf{0}$ & $\mathbf{3}$ & $\mathbf{3}$ & - \\
\hline
\end{tabular}

Bank / Bridge protection types: 0- absent; 1- < 12 inches; 2- < 36 inches; 3- < 48 inches; 4- < 60 inches; 
83. Wingwall and protection comments (eg. undermined penetration, unusual scour processes, etc.):

-
-
-
-
-
-
-

\section{Piers:}

84. Are there piers? (Y or if $N$ type ctrl-n pr)

\begin{tabular}{|l|l|l|l|l|l|l|l|}
\hline \multirow{2}{*}{$\begin{array}{l}85 . \\
\text { Pier no. }\end{array}$} & \multicolumn{3}{|c|}{ width (w) feet } & \multicolumn{3}{c|}{ elevation (e) feet } \\
\cline { 2 - 9 } & w1 & w2 & w3 & e@w1 & e@w2 & e@w3 \\
\hline Pier 1 & - & - & - & - & - & - \\
\hline Pier 2 & - & - & - & - & - & - \\
\hline Pier 3 & - & - & - & - & - & - \\
\hline Pier 4 & - & - & - & - & - & - \\
\hline
\end{tabular}

\begin{tabular}{|l|l|l|l|l|}
\hline Level 1 Pier Descr. & 1 & \multicolumn{1}{|c|}{2} & 3 & \multicolumn{1}{|c|}{} \\
\hline 86. Location (BF) & & - & - & - \\
\hline 87. Type & & - & - & - \\
\hline 88. Material & & - & - & - \\
\hline 89. Shape & & - & - & - \\
\hline 90. Inclined? & & - & - & - \\
\hline 91. Attack $\angle$ (BF) & & - & - & - \\
\hline 92. Pushed & & - & - & - \\
\hline 93. Length (feet) & - & - & - & - \\
\hline 94. \# of piles & & - & - & - \\
\hline 95. Cross-members & & - & - & - \\
\hline 96. Scour Condition & & - & - & - \\
\hline 97. Scour depth & $\mathbf{N}$ & - & - & - \\
\hline 98. Exposure depth & - & - & - & - \\
\hline
\end{tabular}

LFP, LTB, LB, MCL, MCM, MCR, RB, RTB, RFP

1- Solid pier, 2- column, 3- bent

1-Wood; 2-concrete; 3- metal; 4- stone

1- Round; 2- Square; 3- Pointed

Y-yes; $N$ - no

$L B$ or $R B$

0- none; 1- laterals; 2- diagonals; 3- both

0- not evident; 1- evident (comment);

2- footing exposed; 3- piling exposed;

4- undermined footing; 5- settled; 6- failed 
99. Pier comments (eg. undermined penetration, protection and protection extent, unusual scour processes, etc.):

-
-
-
-
-
-
-
-
-

100.

\section{E. Downstream Channel Assessment}

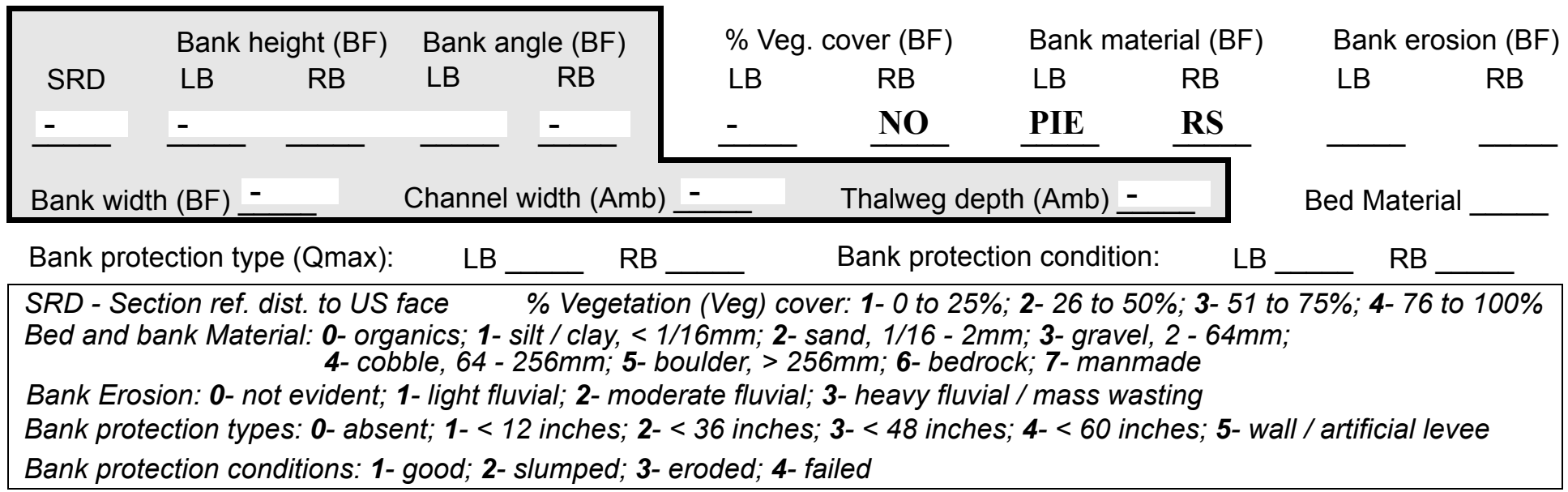

Comments (eg. bank material variation, minor inflows, protection extent, etc.):

3
2
5
5
0
0
432
2
2
1
1

Bank protection on both banks extends from downstream bridge face to 60 feet DS. The banks are protected with boulders and concrete blocks. Additional protection exists on the right bank 200 feet DS where a sharp

101. Is a drop structure present? be (Y or $N$, if $N$ type ctrl-n ds) 102. Distance: ___ feet

103. Drop: -_ feet 104. Structure material: nd (1- steel sheet pile; 2- wood pile; 3- concrete; 4- other)

105. Drop structure comments (eg. downstream scour depth):

in the channel is present.

Bank material is bank protection. There is no bank erosion from bridge face to 60 feet DS. Moderate fluvial erosion exists from 60 feet DS to 200 feet DS on both banks; banks have exposed roots and undermining.

Mass wasting is evident beyond this area. 
106. Point/Side bar present? (Y or $N$. if $N$ type ctrl-n pb)Mid-bar distance:

Mid-bar width:

Point bar extent: feet

(US, UB, DS) to feet (US, UB, DS) positioned $\underline{\mathbf{N}}$ $\%$ LB to $\% \mathrm{RB}$ Material: $\mathbf{N O}$

Point or side bar comments (Circle Point or Side; note additional bars, material variation, status, etc.):

\section{DROP STRUCTURE}

Is a cut-bank present? (Y or if $N$ type ctrl- $n$ cb) Where? (LB or $R B)$

Mid-bank distance: $\underline{\mathbf{N}}$

Cut bank extent: = feet (US, UB, DS) to feet (US, UB, DS)

Bank damage: (1- eroded and/or creep; 2- slip failure; 3- block failure)

Cut bank comments (eg. additional cut banks, protection condition, etc.):

$-$

-

$-$

Is channel scour present? NO (Y or if N type ctrl-n cs) Mid-scour distance: $\underline{\text { POIN }}$ Scour dimensions: Length $\underline{\mathbf{T}}$ Width $\underline{\text { BAR }}$ Depth: $\underline{\mathbf{S}}$ _ Positioned __ \%LB to $\underline{\text { Ref }}$ \%RB Scour comments (eg. additional scour areas, local scouring process, etc.): er to US Assessment for side bar which extends downstream of bridge.

$\mathbf{N}$

Are there major confluences? - $(Y$ or if $N$ type ctrl-n $m c)$ Confluence 1: Distance Enters on (LB or $R B)$ Confluence 2: Distance Enters on $\underline{\mathbf{N O}}$ (LB or RB) How many? Confluence comments (eg. confluence name):

\section{T BANKS}

\section{F. Geomorphic Channel Assessment}

107. Stage of reach evolution

1- Constructed

2- Stable

3- Aggraded

4- Degraded

5- Laterally unstable

6- Vertically and laterally unstable 
108. Evolution comments (Channel evolution not considering bridge effects; See HEC-20, Figure 1 for geomorphic descriptors):

$\mathbf{N}$

$-$

$-$

-

$-$

-

NO CHANNEL SCOUR

Local scour behind boulders.

$\mathbf{N}$ 


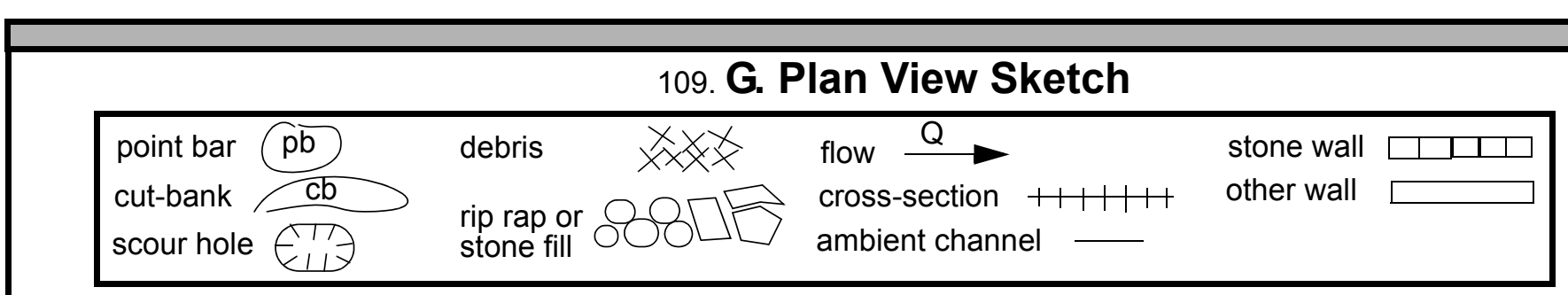


APPENDIX F:

SCOUR COMPUTATIONS 


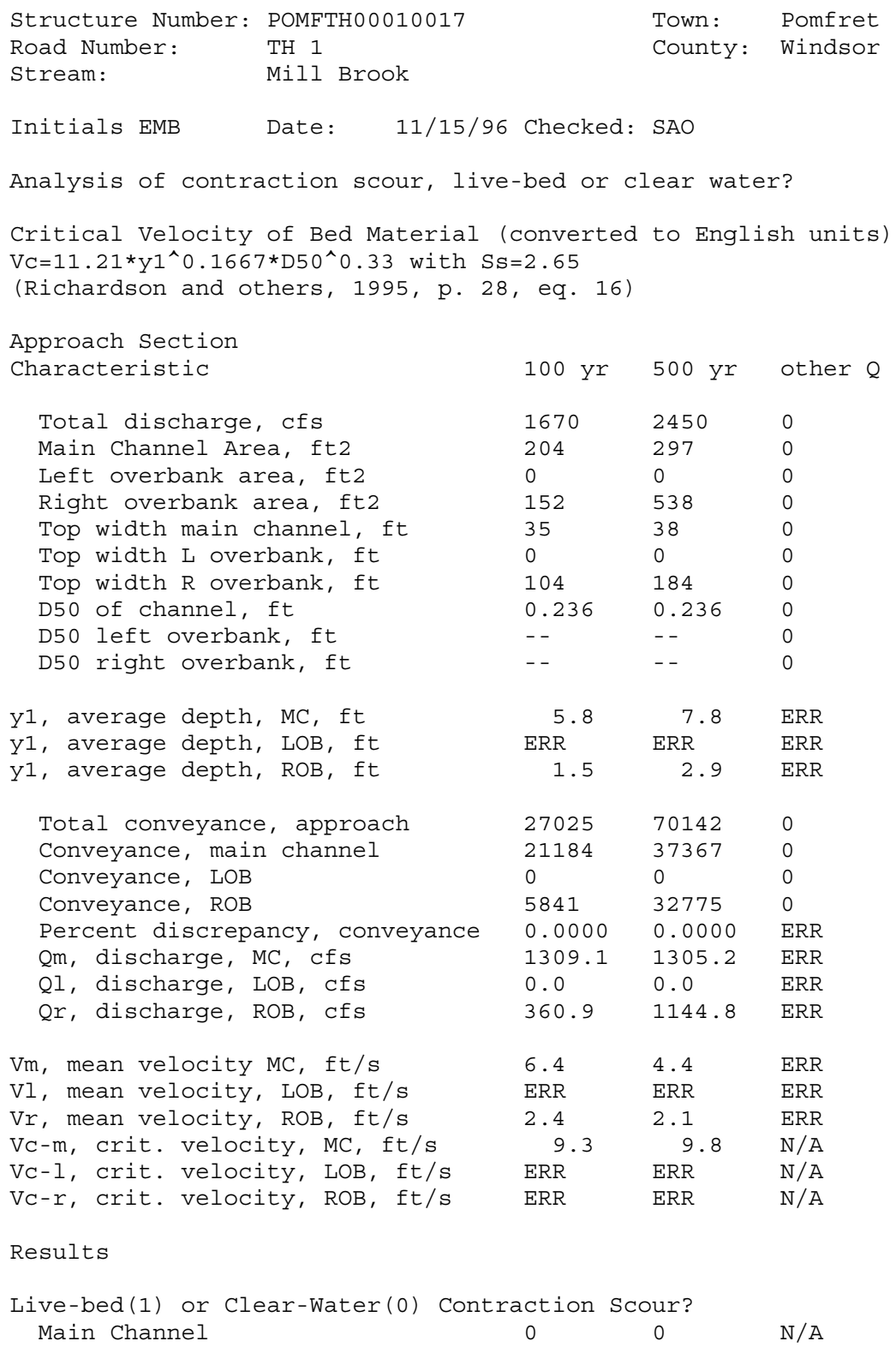


Clear water Contraction Scour in MAIN CHANNEL

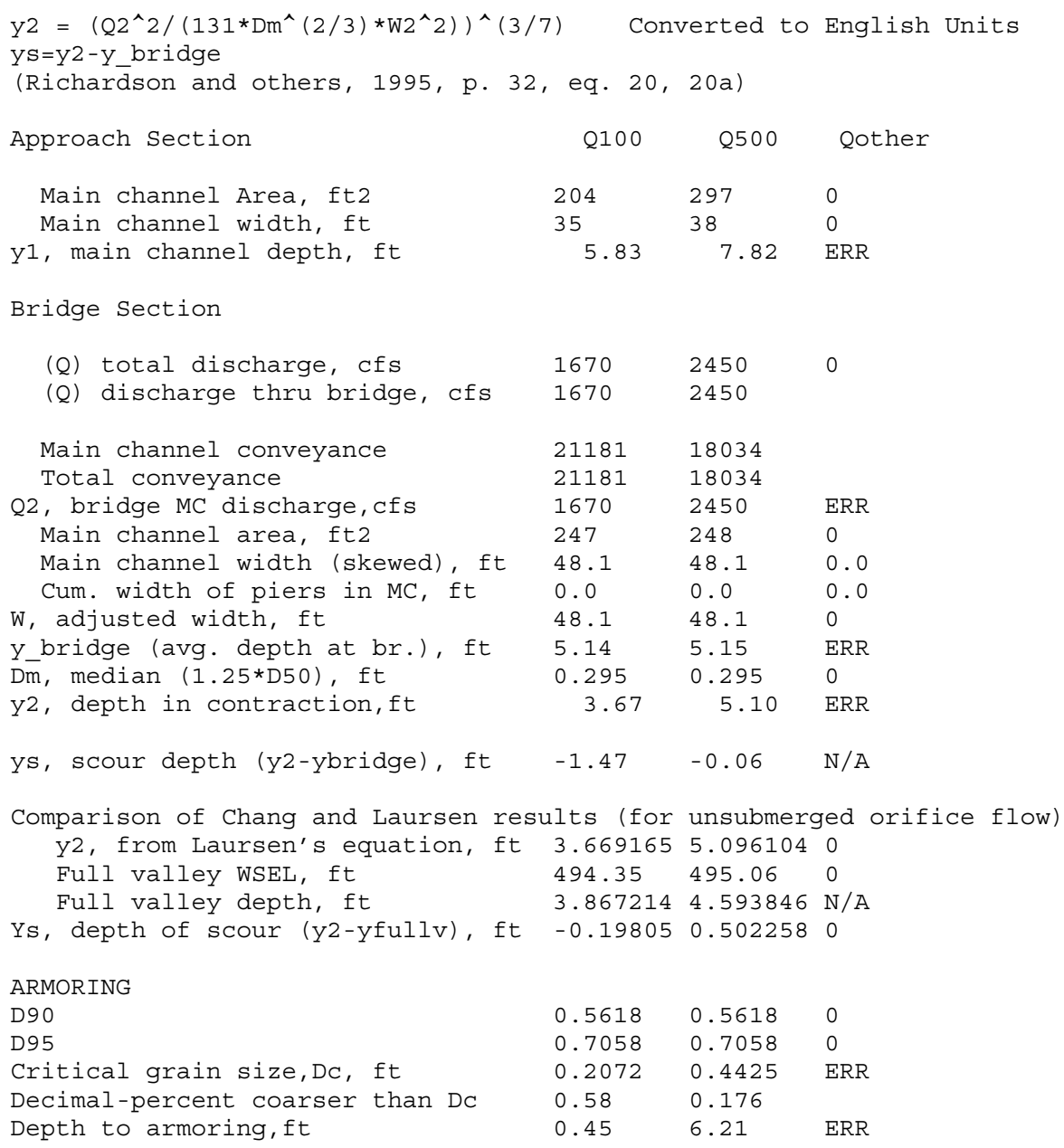


Pressure Flow Scour (contraction scour for orifice flow conditions)

\begin{tabular}{|c|c|c|c|c|}
\hline $\mathrm{Hb}+\mathrm{Ys}=\mathrm{Cq} * \mathrm{qbr} / \mathrm{VC}$ & & $\mathrm{Cf}=1.5^{\prime}$ & $r^{\wedge} 0.43$ & $(<=1)$ \\
\hline $\begin{array}{l}\text { Chang Equation } \\
\text { (Richarson and others, 1995, p. } 145\end{array}$ & $\begin{array}{l}0\left(\mathrm{Hb} /\left(\mathrm{y}^{\circ}\right.\right. \\
-146)\end{array}$ & v) -0.56 & +0.79 & $(<=1)$ \\
\hline & Q100 & Q500 & OtherQ & \\
\hline Q, total, cfs & 1670 & 2450 & 0 & \\
\hline Q, thru bridge, cfs & 1670 & 2450 & 0 & \\
\hline Total Conveyance, bridge & 21181 & 18034 & 0 & \\
\hline Main channel (MC) conveyance, bridge & 21181 & 18034 & 0 & \\
\hline Q, thru bridge MC, Cfs & 1670 & 2450 & ERR & \\
\hline Vc, critical velocity, ft/s & 9.29 & 9.76 & $\mathrm{~N} / \mathrm{A}$ & \\
\hline Vc, critical velocity, m/s & 2.83 & 2.97 & $\mathrm{~N} / \mathrm{A}$ & \\
\hline Main channel width (skewed), ft & 48.1 & 48.1 & 0.0 & \\
\hline Cum. width of piers in MC, ft & 0.0 & 0.0 & 0.0 & \\
\hline w, adjusted width, ft & 48.1 & 48.1 & 0.0 & \\
\hline qbr, unit discharge, $f t^{\wedge} 2 / \mathrm{s}$ & 34.7 & 50.9 & ERR & \\
\hline qbr, unit discharge, $\mathrm{m}^{\wedge} 2 / \mathrm{s}$ & 3.2 & 4.7 & $\mathrm{~N} / \mathrm{A}$ & \\
\hline Area of full opening, $\mathrm{ft}^{\wedge} 2$ & 247.1 & 247.9 & 0.0 & \\
\hline $\mathrm{Hb}$, depth of full opening, ft & 5.14 & 5.15 & ERR & \\
\hline $\mathrm{Hb}$, depth of full opening, $\mathrm{m}$ & 1.57 & 1.57 & $\mathrm{~N} / \mathrm{A}$ & \\
\hline Fr, Froude number, bridge MC & 0.53 & 0.78 & 0 & \\
\hline Cf, Fr correction factor $(<=1.0)$ & 1.00 & 1.00 & 0.00 & \\
\hline Elevation of Low Steel, ft & 495.62 & 495.62 & 0 & \\
\hline Elevation of Bed, ft & 490.48 & 490.47 & $\mathrm{~N} / \mathrm{A}$ & \\
\hline Elevation of Approach, ft & 496.66 & 499.24 & 0 & \\
\hline Friction loss, approach, ft & 0.24 & 0.24 & 0 & \\
\hline Elevation of WS immediately US, ft & 496.42 & 499.00 & 0.00 & \\
\hline ya, depth immediately US, ft & 5.94 & 8.53 & $\mathrm{~N} / \mathrm{A}$ & \\
\hline ya, depth immediately US, m & 1.81 & 2.60 & $\mathrm{~N} / \mathrm{A}$ & \\
\hline Mean elevation of deck, ft & 500.14 & 500.14 & 0 & \\
\hline $\mathrm{w}$, depth of overflow, ft $(>=0)$ & 0.00 & 0.00 & 0.00 & \\
\hline Cc, vert contrac correction $(<=1.0)$ & 0.96 & 0.86 & ERR & \\
\hline Ys, depth of scour, ft & -1.26 & 0.94 & 0.00 & \\
\hline
\end{tabular}




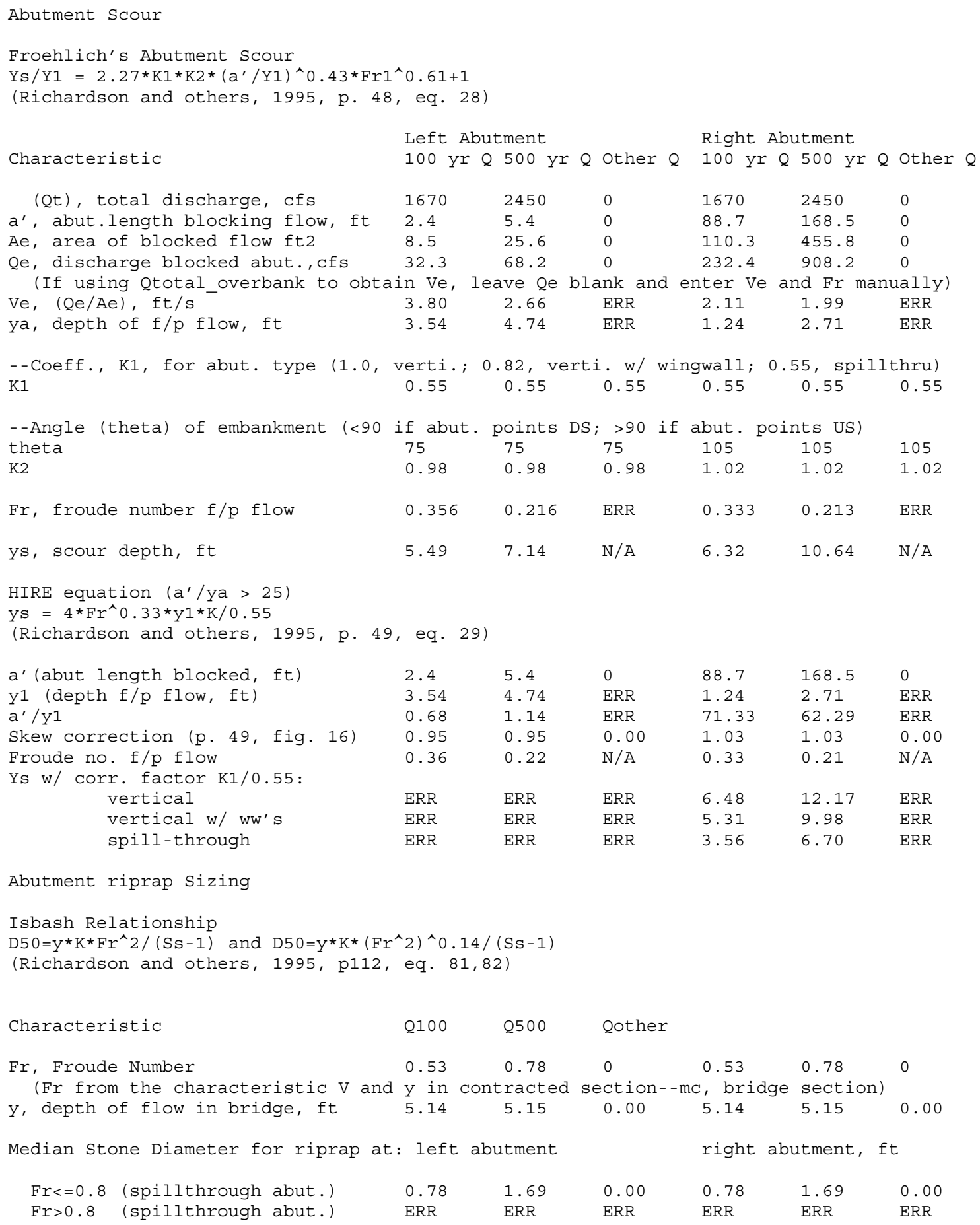

Abutment riprap sizing

Isbash Relationship

$\mathrm{D} 50=\mathrm{Y}^{\star} \mathrm{K} \mathrm{Fr}^{\wedge} 2 /(\mathrm{SS}-1)$ and $\mathrm{D} 50=\mathrm{Y}^{\star} \mathrm{K} *\left(\mathrm{Fr}^{\wedge} 2\right)^{\wedge} 0.14 /(\mathrm{SS}-1)$

(Richardson and others, 1995, p112, eq. 81,82)

$\begin{array}{lll}\text { Characteristic } & \text { Q100 } & \text { Q0ther }\end{array}$

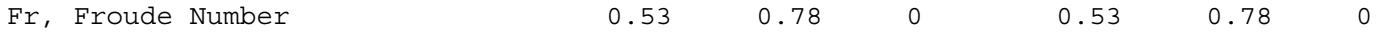
(Fr from the characteristic $V$ and $y$ in contracted section--mc, bridge section) Y, depth of flow in bridge, ft $\quad \begin{array}{lllllll}5.14 & 5.15 & 0.00 & 5.14 & 5.15\end{array}$

Median Stone Diameter for riprap at: left abutment right abutment, ft

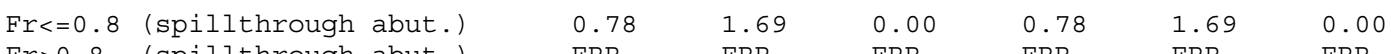
Fr>0.8 (spillthrough abut.) ERR ERR ERR ERR ERR 